\title{
THE PREDICTION OF THE COMBINATION EFFECT OF COMPOST, NITROGEN AND PHOSPHORUS FERTILIZERS ON SOME SOIL PROPERTIES AND PRODUCTIVITY OF WHEAT AND MAIZE YIELDS
}

\author{
Y. A. M. Abd-Allah \\ Soil, Water and Environment Research Inst. Agric. Res. Center, Giza, Egypt
}

Received: Feb. 8, 2021

Accepted: Mar. 22, 2021

\begin{abstract}
Two field experiments were conducted on clayey soil during the two successive seasons, i.e. winter season 2018/2019 using wheat plants and summer season 2019 using maize plants at EL-Gemmieza Agriculture Research Station Agricultural Research Center (ARC) - El Gharbiya Governorate - Egypt (Middle Delta region $30^{\circ}$ 43- latitude and 31\% 47- longitude). The experiments were designed in a randomized complete block design with three replicates to prediction of the most combination of compost, nitrogen and phosphorus fertilizers and its effects on some soil properties and its productivity of crops. Furthermore, economical evaluation was done by calculating the net revenue to determine the most economical treatment. Thirteen treatments having different compost $(\mathrm{C})$, nitrogen $(\mathrm{N})$ and phosphorus $(\mathrm{P})$ were used to cover all possible combinations of these applications as well as control (without any addition). The results were shown in a triangle diagram using a special computer program.
\end{abstract}

The obtained results can be summarized as follows:

1- The individual compost treatment was more effectiveness on reducing $\mathrm{Db}$ and increasing $E$ and $e$ than $N$ and $P$ treatments, as well as Hydraulic conductivity and soil moisture content at harvesting were increased with all treatments compared with the control of the two soil depths at the end of the two seasons. The maximum kh value was obtained by using $100 \%$ compost or $90 \%$ compost $+10 \%$ nitrogen. Also, interaction between $\mathrm{C}, \mathrm{N}$ and $\mathrm{C}, \mathrm{P}$ were more effective on increasing $\mathrm{kh}$.

2- Water consumption (CU) decreased, but water use efficiency (WUE) increased with both individual and combined applications of $C, N$ and $P$ in the two season. The lowest $\mathrm{CU}$ values were recorded with the individual compost treatments in the two seasons.

3- All treatments of $\mathrm{C}, \mathrm{N}$ and $\mathrm{P}$ and their combinations led to decrease in soil $\mathrm{pH}$ and increased soil EC and the soil content of total NPK at the two soil depths in the two seasons compared with control.

4- The addition of $100 \%$ compost (C) gave the highest $O . C$ content, where $C$ was more effective upon increase $0 . C$ than $\mathbf{N}$ and $\mathrm{P}$ which took the order $\mathrm{C}>\mathrm{N}>\mathrm{P}$. While, the maximum $\mathrm{C} / \mathrm{N}$ ratio values were recorded under the treatment consist of $50 \% \mathrm{C}+50 \%$ $P$ in the two seasons.

5- Grans yields and growth characters of wheat and maize plants increased with all the additions of $\mathbf{C}, \mathbf{N}$ and $\mathbf{P}$ alone and in combinations compared with the control, where the highest values were recorded with the treatment consists of $50 \%$ $\mathrm{C}+50 \% \mathrm{~N}$.

6- The obtained results in this study show it is more useful to use $\mathbf{C}, \mathbf{N}$ and $\mathbf{P}$ and their combinations to get a markedly improve in soil physical and chemical properties which reflect on highest yield in incorporated with high net revenue. Where, the highest net revenue (7636.84 LE fed ${ }^{-1}$ ) was recorded by using the treatment consists of $50 \% \mathrm{C}+50 \% \mathrm{~N}$ in the two seasons.

Key words: Compost, Nitrogen, Phosphorus, Soil properties, Wheat and Maize. 


\section{INTRODUCTION}

Most of organic wastes are rich plant nutrients and through proper management such compost can be used as a soil conditioner, as well as a nutrient source for plants Smith (1992) and Keener et al. (2000) mentioned that compost addition not only increase crop yield, but also improve soil fertility in terms of organic $\mathrm{C}, \mathrm{N}$ content, permeability, available water and total porosity. Moyin-Jesu (2015) showed that, the use of the various organic fertilizers (poultry manure, wood ash and rice bran) increased soil $\mathrm{N}, \mathrm{P}, \mathrm{K}, \mathrm{Ca}, \mathrm{Mg}$, and O.M. compared to control. Adugna (2016) reported that organic manures like compost discharge nutrients very slowly to the plants and these nutrients are not directly absorb by the plants. Therefore, plants are unable access required amount of nutrients in the critical yieldforming period. Hence, an integrated approach, combining application of compost with inorganic fertilizer is a good strategy for increasing crop productivity and this will reduce the cost of inorganic fertilizer and improve soil fertility. Liang et al. (2012) stated that decrease in soil $\mathrm{pH}$ could be attributed to the $\mathrm{H}^{+}$ion release by roots, and nitrification and acidification processes stimulated by continuous application of inorganic fertilizer. Organic manure also decrease the $\mathrm{pH}$ due to the organic acid present in organic manure. Mahmood et al. (2017) showed that growth and yield of maize were substantially improved by chemical fertilizers application alongside organic manures, where soil organic C and total $\mathrm{N}, \mathrm{P}, \mathrm{K}$ contents increased when inorganic fertilizers were applied alone or in combined with organic manures. They noted that soil pH and soil bulk density were decreased due to application of organic fertilizer. Jinwei and Lianren (2011) indicated that, the combined application of organic and inorganic fertilizers were the most beneficial method to increase crop yields and improve soil physical and chemical properties rather than using them individually. Bandyopadhyay et al. (2010) reported that the application of organic manure combine with NPK fertilizers lead to increase soil organic carbon, total porosity and hydraulic conductivity and decreased soil bulk density. Chopra et al. (2016) revealed that, the application of different organic manures (poultry manure, FYM and compost) significantly increased grain, straw and biological yields. Mohammed (2017) found that, the cultivated soil with application of FYM had higher soil porosity, aggregate size, organic matter (OM), total macronutrients. Bharath et al. (2017) reported that $\mathrm{N}, \mathrm{P}$ and $\mathrm{K}$ content were significantly higher with interaction of FYM and urban compost, while pH, EC not significantly influenced. Almaz et al. (2017) reported that integrated application of organic and inorganic fertilizer is the best option to improve soil chemical properties and nutrient uptake of maize and soybean. Gamal (2009) observed increased $N, P$ and $K$ nutrients content in all compost received plots and this increase was higher in plots receiving 10 ton ha ${ }^{-1}$ of compost. Gomaa et al. (2015) concluded that spike length (cm), number of grains/spike, number of spikes $/ \mathrm{m}^{2}$, number of spikelets/spike, 1000- grain weight, straw, grain and biological wheat yields were increased by applying $20 \mathrm{FYM} \mathrm{m} / \mathrm{fed}^{-1}+70 \mathrm{kgNfed}^{-}$ ${ }^{1}$.El-Sodany et al. (2009) and El-Maddah et al. (2012) stated that natural soil conditioners (FYM, rock phosphate and sulfur) decreased soil reaction $(\mathrm{pH})$, soil bulk density, water consumptive and increased total soil porosity, void ratio, soil hydraulic conductivity, soil moisture content just before harvesting, water use efficiency, Organic carbon (O.C, \%) and $\mathrm{C} / \mathrm{N}$ ratio compared with control. The experiment of Ahmad et al. (2013) shown 
that, combining organic sources with $50 \%$ of recommended NPK fertilizers occurred a significant encreased in grain and biological yields of maize and the net return was also increased. Tayebeh et al. (2010) reported that, combined organic and inorganic fertilizers resulted the highest wheat yield without any negative effect on seed quality. They added that compost could be replaced $30 \%$ of the nitrogen requirement by plant. In addition, less use of $\mathbf{N}$ fertilization will lead to environmental conversation. Brown and Cotton (2011) observed that, soil bulk density decreased by increasing the compost rates. In addition, the organic fraction is much lighter in weight than the mineral fraction in soil as a result to increase in the organic fraction decrease the total weight and bulk density of the soil. In this context Liu et al. (2007) found that, low bulk density indicates increased pore space and is indicative of improved soil tilth. In this respect, compost increases the portion of micro and macro-pores as a result to improve soil aggregation. Amit et al. (2018) reported that a marked increase occurred in crop yield upon compost application as a result of improving soil physical and chemical properties.

The prediction of the combination effect of compost, nitrogen and phosphorus fertilizers on some soil properties and the productivity of crops is the objective of this experiment. Furthermore, economical evaluation was done by calculating the net revenue to determine the economical treatment.

\section{MATERIALS AND METHODS}

Two field experiments were carried out on clayey soils at El-Gemmeiza Agricultural Research Station Agricultural Research Center (ARC) - EI Gharbiya Governorate - Egypt (Middle Delta region $30^{\circ}$ 43- latitude and 31 47 longitude) during two seasons, winter growing season 2018/2019 using wheat plant (Triticum aestivum., L.) and summer season 2019 using maize plant (Zea mays., $L$.) as tested plants to prediction of the combination effect of compost, nitrogen and phosphorus fertilizers on some soil properties and the tested crops productivity. At the same time a three - factors computer program was used to predict the best treatment of the studied applications effect on the determined parameters. Furthermore, economical evaluation was done by calculating the net revenue to determine the economical treatment. The initial properties of the experimental soil before planting in the first and second seasons were studied at soil depth of $0-20$ and 20$40 \mathrm{~cm}$ are presented in Table (1-a) and properties of the used plant compost are shown in Table (1-b).

Computer model represented by Gipsea diagram according to Moussa et al. (1986) and Moussa (1991) was applied on this study. The three studied factors were compost (X1), nitrogen (X2) and phosphate (X3). The level of each factor was represented by one hand of triangle. The amounts of each factor ranged between $100 \%$ as its maximum value and decreased gradually when moving from the concerned head towards the opposite side at which the level reaches to zero.

Each hand of triangle is divided into ten sections, where each section represented by $10 \%$, therefore the triangle consists of 66 intersection (combinations) cover all the possible combinations of compost, nitrogen and phosphorus. Thirteen intersection treatments from the triangle were chosen to carry out those experiments, Table (1c) and Figs. (1 and 2), beside the control (treatment No. 14) where no addition were used.

The maximum rates of compost were 4213.48 and $6741.57 \mathrm{Kg} \mathrm{fed}^{-1}$ for wheat and maize plants in the first and second 
growing seasons, respectively. Also, during the two seasons the basal doses of $\mathrm{N}, \mathrm{P}$ and $\mathrm{K}$ were applied according to the recommendations for each crop. For wheat plant, $75 \mathrm{Kg} \mathrm{N} \mathrm{fed}^{-1}$ as ammonium nitrate $(33.5 \% \mathrm{~N}), 15.5 \mathrm{Kg} \mathrm{P}_{2} \mathrm{O}_{5}$ fed $^{-1}$ as supper phosphate $\left(15.5 \% \mathrm{P}_{2} \mathrm{O}_{5}\right)$ and 12
$\mathrm{Kg} \mathrm{K}_{2} \mathrm{O} \mathrm{fed}^{-1}$ as potassium sulphate $(48 \%$ $\mathrm{K}_{2} \mathrm{O}$ ) were added. Also, $120 \mathrm{Kg} \mathrm{N} \mathrm{fed}^{-1}$ in the form of ammonium nitrate, $31 \mathrm{Kg}$ $\mathrm{P}_{2} \mathrm{O}_{5} \mathrm{fed}^{-1}$ in the form of supper phosphate and $24 \mathrm{Kg} \mathrm{K} O$ fed $^{-1}$ in the form of potassium sulphate were used for maize plant.

Table (1-a): Some soil characters in the first and second seasons.

\begin{tabular}{|c|c|c|c|c|c|c|c|c|c|c|}
\hline \multirow{2}{*}{\multicolumn{2}{|c|}{$\begin{array}{c}\text { Properties } \\
\text { Soil depth, cm }\end{array}$}} & \multicolumn{2}{|c|}{ First season } & \multicolumn{2}{|c|}{$\begin{array}{l}\text { Second } \\
\text { season }\end{array}$} & \multirow{2}{*}{\begin{tabular}{|r} 
Properties \\
Soil depth, cm \\
\end{tabular}} & \multicolumn{2}{|c|}{$\begin{array}{c}\text { First } \\
\text { season }\end{array}$} & \multicolumn{2}{|c|}{$\begin{array}{l}\text { Second } \\
\text { season }\end{array}$} \\
\hline & & $0-20$ & $20-40$ & $0-20$ & $20-40$ & & $0-20$ & $20-40$ & $0-20$ & \begin{tabular}{|l|}
$20-$ \\
40
\end{tabular} \\
\hline \multicolumn{11}{|c|}{ Soil physical properties } \\
\hline \multirow{4}{*}{ 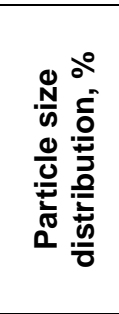 } & $\begin{array}{l}\text { Coarse } \\
\text { sand }\end{array}$ & 3.32 & 3.21 & 3.32 & 3.21 & $\begin{array}{l}\text { Bulk density (Db, g } \\
\mathrm{cm}^{-3} \text { ) }\end{array}$ & 1.36 & 1.38 & 1.32 & 1.36 \\
\hline & \begin{tabular}{|l|} 
Fine \\
sand
\end{tabular} & 15.26 & 15.12 & 15.26 & 15.12 & Total porosity (E, \%) & 48.68 & 47.92 & 50.19 & 48.68 \\
\hline & Silt & 34.23 & 33.86 & 34.23 & 33.86 & Void ratio $(e)$ & 0.95 & 0.92 & 1.01 & 0.95 \\
\hline & Clay & 47.19 & 47.81 & 47.19 & 47.81 & $\begin{array}{l}\text { Hydraulic } \\
\text { conductivity }(\mathrm{Kh}, \\
\left.\mathrm{cm} \mathrm{hr^{-1 }}\right) \\
\end{array}$ & 0.47 & 0.44 & 0.51 & 0.49 \\
\hline \multicolumn{2}{|c|}{ Texture class } & Clayey & Clayey & Clayey & Clayey & \multirow{2}{*}{$\begin{array}{l}\text { Soil moisture } \\
\text { content, \% }\end{array}$} & \multirow{2}{*}{16.17} & \multirow{2}{*}{19.65} & \multirow{2}{*}{15.29} & \multirow{2}{*}{17.98} \\
\hline \multicolumn{2}{|c|}{$\mathrm{CaCO}_{3}, \%$} & 3.35 & 3.21 & 3.27 & 3.18 & & & & & \\
\hline \multicolumn{11}{|c|}{ Soil chemical properties } \\
\hline \multicolumn{2}{|c|}{$\begin{array}{l}\text { Soil pH, 1:2.5 } \\
\text { (suspension) }\end{array}$} & 7.73 & 7.83 & 7.72 & 7.80 & $\begin{array}{l}\text { Soil EC, } \mathrm{dSm}^{-1} \text { (soil } \\
\text { paste extract) }\end{array}$ & 2.33 & 2.74 & 2.36 & 2.79 \\
\hline \multirow{7}{*}{ 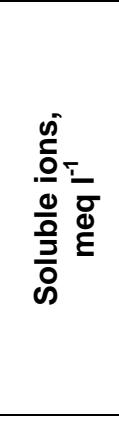 } & $\mathrm{Ca}^{++}$ & 8.61 & 9.89 & 8.51 & 10.03 & $\begin{array}{l}\text { Organic matter } \\
\text { (O.M., \%) }\end{array}$ & 2.72 & 2.38 & 2.71 & 2.38 \\
\hline & $\mathrm{Mg}^{++}$ & 7.11 & 8.76 & 7.69 & 9.17 & $\begin{array}{l}\text { Organic carbon } \\
\text { (O.C., \%) }\end{array}$ & 1.58 & 1.38 & 1.57 & 1.38 \\
\hline & $\mathrm{Na}^{+}$ & 7.21 & 8.43 & 6.85 & 8.21 & $\begin{array}{l}\text { Total nitrogen (T.N., } \\
\%)\end{array}$ & 0.146 & 0.134 & 0.150 & 0.138 \\
\hline & $\mathrm{K}^{+}$ & 0.37 & 0.33 & 0.54 & 0.49 & C/N ratio & 10.82 & 10.30 & 10.47 & 10.00 \\
\hline & $\mathrm{HCO}_{3}{ }^{-}$ & 7.26 & 8.44 & 7.21 & 8.50 & Total P (T.P., \%) & 0.040 & 0.038 & 0.043 & 0.041 \\
\hline & $\mathrm{CL}^{-}$ & 9.79 & 11.09 & 10.18 & 11.55 & \multirow{2}{*}{ Total K (T.K., \%) } & \multirow{2}{*}{0.346} & \multirow{2}{*}{0.330} & \multirow{2}{*}{0.355} & \multirow{2}{*}{0.342} \\
\hline & $\mathrm{SO}_{4}$ & 6.25 & 7.88 & 6.20 & 7.85 & & & & & \\
\hline
\end{tabular}

Table (1-b): Some characteristics of the used plant compost.

\begin{tabular}{|l|c|l|c|}
\hline \multicolumn{1}{|c|}{ Properties } & Value & \multicolumn{1}{c|}{ Properties } & Value \\
\hline pH (1:10 compost: water) susp. & 7.39 & Available Cu, mgkg $^{-1}$ & 31.25 \\
\hline EC, $\mathrm{dS} \mathrm{m}^{-1}$ (1:10 compost: water) extract. & 3.19 & Ash, \% & 66.33 \\
\hline $\mathrm{Ca}, \%$ & 0.84 & Organic matter, \% & 33.67 \\
\hline $\mathrm{Mg}, \%$ & 0.29 & Organic carbon, \% & 19.53 \\
\hline $\mathrm{Na}, \%$ & 0.27 & Total N, \% & 1.78 \\
\hline Available $\mathrm{Fe}, \mathrm{mgkg}^{-1}$ & 1215 & C/N ratio & 10.97 \\
\hline Available $\mathrm{Zn}, \mathrm{mgkg}^{-1}$ & 83.15 & Total P, \% & 0.95 \\
\hline Available $\mathrm{Mn}, \mathrm{mgkg}^{-1}$ & 72.8 & Total K, \% & 1.6 \\
\hline
\end{tabular}


The prediction of the combination effect of compost, nitrogen and

Table (1-c) : The chosen combinations of application treatments

\begin{tabular}{|c|c|c|c|c|c|c|c|c|c|}
\hline \multirow{3}{*}{ 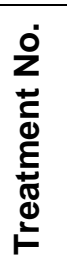 } & \multirow{2}{*}{\multicolumn{3}{|c|}{$\begin{array}{c}\text { Relative } \\
\text { fractional as unit }\end{array}$}} & \multicolumn{6}{|c|}{ Amount of application treatments } \\
\hline & & & & \multicolumn{3}{|c|}{ First season } & \multicolumn{3}{|c|}{ Second season } \\
\hline & $\mathrm{X}_{1}$ & $X_{2}$ & $X_{3}$ & $\begin{array}{c}\text { Compost, } \\
\text { C, } \\
\text { Ton fed }^{-1}\end{array}$ & $\begin{array}{c}\text { Nitrogen, } \\
\mathrm{N}, \mathrm{Kg} \\
\text { fed }^{-1}\end{array}$ & $\begin{array}{c}\text { Phosphorus } \\
\mathrm{P}_{2} \mathrm{O}_{5}, \mathrm{Kg} \\
\text { fed }^{-1}\end{array}$ & $\begin{array}{c}\text { Compost, } \\
\text { C, } \\
\text { Ton fed }^{-1}\end{array}$ & $\begin{array}{c}\text { Nitrogen, } \\
\mathrm{N}, \mathrm{Kg} \\
\text { fed }^{-1}\end{array}$ & $\begin{array}{c}\text { Phosphorus, } \\
\mathrm{P}_{2} \mathrm{O}_{5}, \mathrm{Kg} \\
\text { fed }^{-1}\end{array}$ \\
\hline 1 & 100 & 0 & 0 & 4.213 & 0 & 0 & 6.742 & 0 & 0 \\
\hline 2 & 0 & 100 & 0 & 0.000 & 75.00 & 0 & 0.000 & 120.00 & 0 \\
\hline 3 & 0 & 0 & 100 & 0.000 & 0 & 15.50 & 0.000 & 0 & 31.00 \\
\hline 4 & 50 & 50 & 0 & 2.107 & 37.50 & 0.00 & 3.371 & 60.00 & 0.00 \\
\hline 5 & 50 & 0 & 50 & 2.107 & 0.00 & 7.75 & 3.371 & 0.00 & 15.50 \\
\hline 6 & 0 & 50 & 50 & 0.000 & 37.50 & 7.75 & 0.000 & 60.00 & 15.50 \\
\hline 7 & 33.3 & 33.3 & 33.3 & 1.403 & 24.98 & 5.16 & 2.245 & 39.96 & 10.32 \\
\hline 8 & 66.6 & 16.6 & 16.6 & 2.806 & 12.45 & 2.57 & 4.490 & 19.92 & 5.15 \\
\hline 9 & 16.6 & 66.6 & 16.6 & 0.699 & 49.95 & 2.57 & 1.119 & 79.92 & 5.15 \\
\hline 10 & 16.6 & 16.6 & 66.6 & 0.699 & 12.45 & 10.32 & 1.119 & 19.92 & 20.65 \\
\hline 11 & 44.4 & 44.4 & 11.1 & 1.871 & 33.30 & 1.72 & 2.993 & 53.28 & 3.44 \\
\hline 12 & 44.4 & 11.1 & 44.4 & 1.871 & 8.33 & 6.88 & 2.993 & 13.32 & 13.76 \\
\hline 13 & 11.1 & 44.4 & 44.4 & 0.468 & 33.30 & 6.88 & 0.748 & 53.28 & 13.76 \\
\hline
\end{tabular}

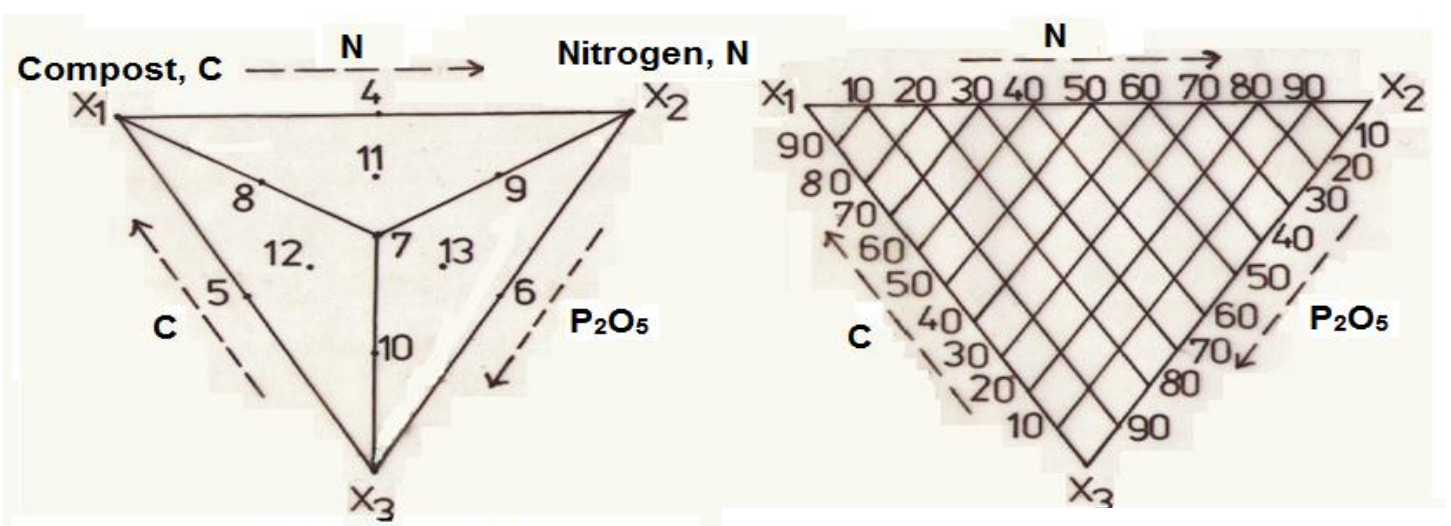

Phosphate, $\mathrm{P}_{2} \mathrm{O}_{5}$

Fig. (1): Location of the thirteen chosen treatments on the triangle diagram

The plot area of the experiments was $42 \mathrm{~m}^{2}(6 \times 7 \mathrm{~m})$ this study was carried out in a randomized complete block design with three replicates. Compost was added on basis total $N(1.78 \%)$ and homogenously mixed with the $0-20 \mathrm{~cm}$ surface layer before sowing in the first and second seasons. Wheat grains (Giza 168 variety) were planted on $19^{\text {th }}$
Fig. (2): Guide for $C, N$ and $P$ combination of each point.

November in the first season (2018/2019) at the rate of $60 \mathrm{Kg} / \mathrm{fed}$., while maize grains (Zea mays, three-way cross, Giza 329) were planted on $8^{\text {th }}$ June in the second one (2019) at the rate of 15 $\mathrm{Kgfed}^{-1}$. During the two seasons, the normal cultural practices of El-Gemmeiza Research Station were adopted. 
At harvesting of each growing season, undisturbed and disturbed soil samples at soil depth of $0-20$ and $20-40 \mathrm{~cm}$ were collected from each plot. The disturbed soil samples were air-dried, ground and passed through $2 \mathrm{~mm}$ sieve and stored for determine some soil chemical properties. Undisturbed soil samples were used to determine some soil physical and hydro physical properties.

Soil bulk density (Db, $\mathrm{gcm}^{-3}$ ) was determined using the core methods (Vomocil, 1986). Total porosity $(E, \%)$ and void ratio (e) were calculated using the following equations:-

$$
E, \%=\left(1-\frac{D b}{D r}\right) \times 100
$$

and $e=\frac{D r}{D b}-1$

Where: $\mathrm{Db}=$ the bulk density, $\mathrm{gcm}^{-3}$

$$
\mathrm{Dr}=\text { the real density, } \mathrm{gcm}^{-3}
$$

Hydraulic conductivity $\left(\mathrm{cmhr}^{-1}\right)$ was determined using undisturbed soil cores using a constant water head according to Richards (1954). Soil moisture content $(\Theta w, \%)$ were determined using the method outlined by Stakman (1969). Water consumption (CU) was determined by collecting soil samples from each plot before and after 48 hours of every irrigation and computed according to the equation of Israelsen and Hansen (1962) as follows.

Water consuption, $c m=\frac{\theta_{2}-\theta_{1}}{100} \times D b \times D$

Where:

$\theta_{2}=$ Soil moisture percentage on weight basis after 48 hours from irrigation.

$\theta_{1}=$ Soil moisture percentage before irrigation.

$\mathrm{Db}=$ Bulk density, $\mathrm{g} / \mathrm{cm}^{-3}$

D = Soil depth, cm

Water use efficiency (WUE) was calculated by dividing the grain yield of wheat and maize $\left(\mathrm{kgfed}^{-1}\right)$ by water consumptive use $(\mathrm{cm})$ according to the equation of Jensen (1983):
WUE, $\mathrm{kg} \mathrm{fed}^{-1} \mathrm{~cm}^{-1}=\frac{\text { Grain yield },\left(\mathrm{kg} \mathrm{fed}^{-1}\right)}{\text { Water consumption }(\mathrm{cm})}$

Soil $\mathrm{pH}$ in soil water suspension (1: 2.5) and soil electrical conductivity (EC, $\mathrm{dSm}^{-1}$ ) in soil paste extract were measured. Organic matter was determined by Walkely and Black method according to Black (1965). The content of total NPK of the soil were determined according to Hesse (1971). Total nitrogen was determined by macro-Kjeldahel method, total phosphorus was measured calorimetrically using ascorbic acid and total potassium was measured by flame photometer method.

Ten random plants of each plot were randomized sampled of each crop to determine the following characters.

Wheat growth characters.

1- Plant height, $\mathrm{cm}$ 2- Spike length, cm

3- Dry matter after 90 days of sowing, $\mathrm{g}$ 10 plants $^{-1}$

Maize growth characters:

1- Plant height, (cm) 2- Ear length, (cm)

3- Ear diameter, $(\mathrm{cm})$

4- Number of rows per ear.

5- Number of kernels per row

6- Dry matter after 80 days of sowing ( 9 plant $^{-1}$ )

At harvest stage of both wheat and maize yields for each plot was separately harvested, weighted and related to tons fed $^{-1}$, also wheat straw (tons fed ${ }^{-1}$ ). 1000 wheat seed and 100 corn seed weight were recorded for each treatment.

The collected data were passed through the computer program to receive results represented on the triangle at the same site of the concerned combined treatments. The maximum value will be represented by number 10 and printed in a place form which the combination treatment resulted, other figures will shown values related to the maximum one. Moreover, the computer output 
shows the average value, correlation coefficient, fisher criterion, coefficient determination, maximum and minimum value.

Economic evaluation was done to compare between different treatments to state which one is the best. The test was executed according to the price of the grains and straw yields were 4467.00 and 1000 LE ton $^{-1}$, respectively for wheat in the first season and was 2105 LE ton $^{-1}$ for maize grains in the second season, as well as the cost of different treatments including the price of the addition treatments and the price of labor they added, which was calculated considering conventional method of estimating both fixed and variable costs.

\section{RESULTS AND DISCUSSION}

Effect of different treatments on some soil physical properties.

Soil bulk density (Db), total porosity (E) and void ratio (e).

The results in Table (2 and 3 ) show that, most of soil physical characters were affected by application of compost, nitrogen and phosphorus compared with the control. The lowest $\mathrm{Db}$ values were 1.24 and $1.26 \mathrm{~g} \mathrm{~cm}^{-3}$ in the soil depth of 0 20 and $20-40 \mathrm{~cm}$, respectively in the first season and were 1.08 and $1.13 \mathrm{~g} \mathrm{~cm}^{-3}$ at the same soil depths, respectively in the second season. Whereas, the found values of $E$ and $e$ took the opposite trend, where the highest $E$ values were $\mathbf{5 3 . 2 1}$ and $52.45 \%$ at the two soil depths, respectively in the first season and were 59.25 and $57.36 \%$ at the same depths in the second season. Data in Fig. (3) cleared that, the highest $E$ value was $53.21 \%$ denoted by number 10 was a achieved by the individual compost treatment $(100 \%$ compost) at the surface soil layer in the first season. Also the results in Tables (2 and 3 ) and Fig. (3) it can be concluded that, the individual compost treatment was more effectiveness on reducing $\mathrm{Db}$ and increasing $E$ and $e$ than the other treatments at the two soil depths after wheat and maize harvesting. These results may be attribute to the increase in soil organic matter content induced by compost decomposition and concomitant increase in both soil total porosity and void ratio. These results are in agreement with liu et al. (2007) they said that low bulk density indicates increased pores spaces and in this respect, compost increases the portion of macro and micro pores as a result of improve soil aggregation.

\section{Effect of different treatments on some soil hydrophisical properties.}

1- Hydraulic conductivity (kh) and soil moisture content at harvesting $(\theta w)$.

Data in Tables (2 and 3) show that hydraulic conductivity and soil moisture content at harvesting were increased with all the experimental treatments compared with the control at $0-20$ and 20 $40 \mathrm{~cm}$ soil depths at the end of the two growing seasons. The highest kh values were 0.62 and $0.60 \mathrm{~cm} \mathrm{hr}^{-1}$ at the two soil depths, respectively in the first season and were 0.69 and $0.63 \mathrm{~cm} \mathrm{hr}^{-1}$ at the same depths in the second season. Also the highest $\theta \mathrm{w}$ values were 20.96 and $23.83 \%$ at the two soil depths, respectively in the first season and were 18.41 and $21.01 \%$ at the same soil depths, respectively in the second season. 
Table (2): Effect of different treatments on some soil physical and hydrophysical properties after wheat in the first season (winter 2018/2019)

\begin{tabular}{|c|c|c|c|c|c|c|c|c|c|c|c|c|}
\hline \multirow{3}{*}{ 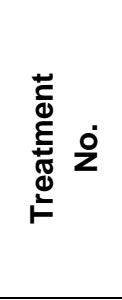 } & \multicolumn{12}{|c|}{ First season } \\
\hline & \multicolumn{2}{|c|}{$\begin{array}{l}\text { Bulk density, } \\
\text { Db, gmcm }\end{array}$} & \multicolumn{2}{|c|}{$\begin{array}{c}\text { Total } \\
\text { porosity E, \% }\end{array}$} & \multicolumn{2}{|c|}{$\begin{array}{l}\text { Void ratio } \\
\text { (e) }\end{array}$} & \multicolumn{2}{|c|}{$\begin{array}{c}\text { Hydraulic } \\
\text { conductivity } \\
\left(\mathrm{Kh}, \mathrm{cmhr}^{-1}\right)\end{array}$} & \multicolumn{2}{|c|}{$\begin{array}{c}\text { Soil moisture } \\
\text { content ( }(\Theta w, \\
\%) \text { at } \\
\text { harvesting }\end{array}$} & \multirow{2}{*}{ 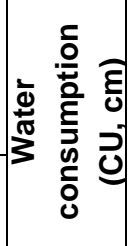 } & \multirow{2}{*}{ 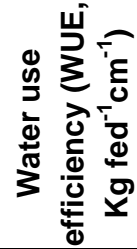 } \\
\hline & $\begin{array}{c}0-20 \\
\mathrm{~cm}\end{array}$ & $\begin{array}{c}20-40 \\
\mathrm{~cm}\end{array}$ & $\begin{array}{l}0-20 \\
\mathrm{~cm}\end{array}$ & $\begin{array}{c}20-40 \\
\mathrm{~cm}\end{array}$ & $\begin{array}{c}0-20 \\
\mathrm{~cm}\end{array}$ & $\begin{array}{c}20-40 \\
\mathrm{~cm}\end{array} \mid$ & $\begin{array}{l}0-20 \\
\mathrm{~cm}\end{array}$ & $\begin{array}{c}20-40 \\
\mathrm{~cm}\end{array}$ & $\begin{array}{c}0-20 \\
\mathrm{~cm}\end{array}$ & $\begin{array}{c}20-40 \\
\mathrm{~cm}\end{array}$ & & \\
\hline 1 & 1.24 & 1.26 & 53.21 & 52.45 & 1.14 & 1.10 & 0.62 & 0.60 & 20.96 & 23.83 & 30.40 & 136.88 \\
\hline 2 & 1.32 & 1.34 & 50.19 & 49.43 & 1.01 & 0.98 & 0.53 & 0.51 & 18.21 & 21.51 & 36.72 & 108.62 \\
\hline 3 & 1.33 & 1.36 & 49.81 & 48.68 & 0.99 & 0.95 & 0.50 & 0.48 & 17.41 & 20.65 & 37.11 & 97.21 \\
\hline 4 & 1.26 & 1.29 & 52.45 & 51.32 & 1.10 & 1.05 & 0.60 & 0.58 & 20.39 & 23.25 & 30.42 & 143.98 \\
\hline 5 & 1.27 & 1.30 & 52.08 & 50.94 & 1.09 & 1.04 & 0.59 & 0.57 & 20.19 & 23.05 & 31.02 & 125.39 \\
\hline 6 & 1.33 & 1.37 & 49.81 & 48.30 & 0.99 & 0.93 & 0.49 & 0.47 & 16.66 & 20.17 & 37.79 & 103.07 \\
\hline 7 & 1.29 & 1.32 & 51.32 & 50.19 & 1.05 & 1.01 & 0.57 & 0.54 & 19.74 & 22.71 & 33.70 & 115.84 \\
\hline 8 & 1.26 & 1.29 & 52.45 & 51.32 & 1.10 & 1.05 & 0.60 & 0.58 & 20.23 & 23.10 & 30.42 & 133.26 \\
\hline 9 & 1.30 & 1.32 & 50.94 & 50.19 & 1.04 & 1.01 & 0.57 & 0.54 & 19.60 & 22.60 & 33.95 & 121.03 \\
\hline 10 & 1.30 & 1.33 & 50.94 & 49.81 & 1.04 & 0.99 & 0.56 & 0.54 & 19.43 & 22.52 & 34.94 & 107.57 \\
\hline 11 & 1.27 & 1.30 & 52.08 & 50.94 & 1.09 & 1.04 & 0.58 & 0.56 & 20.17 & 23.04 & 31.82 & 136.14 \\
\hline 12 & 1.28 & 1.29 & 51.70 & 51.32 & 1.07 & 1.05 & 0.57 & 0.55 & 20.17 & 23.04 & 32.15 & 117.54 \\
\hline 13 & 1.31 & 1.33 & 50.57 & 49.81 & 1.02 & 0.99 & 0.56 & 0.53 & 19.25 & 22.35 & 35.89 & 107.14 \\
\hline Control & 1.35 & 1.38 & 49.06 & 47.92 & 0.96 & 0.92 & 0.48 & 0.45 & 16.18 & 19.86 & 38.20 & 72.18 \\
\hline
\end{tabular}

Table (3): Effect of different treatments on some soil physical and hydrophysical properties after maize in the second season (summer 2019)

\begin{tabular}{|c|c|c|c|c|c|c|c|c|c|c|c|c|}
\hline \multirow{3}{*}{ 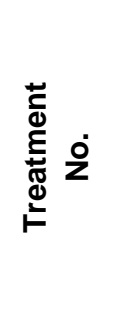 } & \multicolumn{12}{|c|}{ Second season } \\
\hline & \multicolumn{2}{|c|}{$\begin{array}{l}\text { Bulk density, } \\
\text { Db, gmcm }\end{array}$} & \multicolumn{2}{|c|}{$\begin{array}{c}\text { Total } \\
\text { porosity E, \% }\end{array}$} & \multicolumn{2}{|c|}{$\begin{array}{c}\text { Void ratio } \\
\text { (e) }\end{array}$} & \multicolumn{2}{|c|}{$\begin{array}{l}\text { Hydraulic } \\
\text { conductivity } \\
\left(\mathrm{Kh}, \mathrm{cmhr}^{-1}\right)\end{array}$} & \multicolumn{2}{|c|}{$\begin{array}{c}\text { Soil moisture } \\
\text { content }(\Theta w, \\
\%) \text { at } \\
\text { harvesting }\end{array}$} & \multirow{2}{*}{ 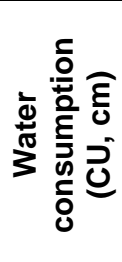 } & \multirow{2}{*}{ 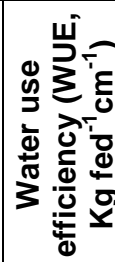 } \\
\hline & $\begin{array}{c}0-20 \\
\mathrm{~cm}\end{array}$ & $\begin{array}{c}20-40 \\
\mathrm{~cm}\end{array}$ & $\begin{array}{c}0-20 \\
\mathrm{~cm}\end{array}$ & $\begin{array}{c}20-40 \\
\mathrm{~cm}\end{array}$ & $\begin{array}{c}0-20 \\
\mathrm{~cm}\end{array}$ & $\begin{array}{c}20-40 \\
\mathrm{~cm}\end{array} \mid$ & $\begin{array}{c}0-20 \\
\mathrm{~cm}\end{array}$ & $\begin{array}{c}20-40 \\
\mathrm{~cm}\end{array}$ & $\begin{array}{c}0-20 \\
\mathrm{~cm}\end{array}$ & $\begin{array}{c}20-40 \\
\mathrm{~cm}\end{array}$ & & \\
\hline 1 & 1.08 & 1.13 & 59.25 & 57.36 & 1.45 & 1.35 & 0.69 & 0.63 & 18.41 & 21.01 & 50.23 & 60.24 \\
\hline 2 & 1.22 & 1.26 & 53.96 & 52.45 & 1.17 & 1.10 & 0.57 & 0.55 & 16.56 & 19.29 & 63.82 & 45.19 \\
\hline 3 & 1.23 & 1.29 & 53.58 & 51.32 & 1.15 & 1.05 & 0.54 & 0.52 & 15.92 & \begin{tabular}{|l|}
18.54 \\
\end{tabular} & 64.09 & 39.83 \\
\hline 4 & 1.12 & 1.15 & 57.74 & 56.60 & 1.37 & 1.30 & 0.69 & 0.63 & 18.40 & 20.85 & 54.33 & 57.55 \\
\hline 5 & 1.12 & 1.15 & 57.74 & 56.60 & 1.37 & 1.30 & 0.66 & 0.62 & 18.37 & 20.57 & 55.08 & 49.71 \\
\hline 6 & 1.26 & 1.31 & 52.45 & 50.57 & 1.10 & 1.02 & 0.53 & 0.51 & 15.57 & 18.23 & 64.98 & 42.63 \\
\hline 7 & 1.17 & 1.21 & 55.85 & 54.34 & 1.26 & 1.19 & 0.62 & 0.58 & 15.35 & 20.15 & 58.90 & 47.26 \\
\hline 8 & 1.12 & 1.15 & 57.74 & 56.60 & 1.37 & 1.30 & 0.66 & 0.63 & 18.40 & 20.61 & 55.08 & 54.10 \\
\hline 9 & 1.17 & 1.22 & 55.85 & 53.96 & 1.26 & 1.17 & 0.61 & 0.58 & 17.24 & 20.04 & 59.09 & 50.89 \\
\hline 10 & 1.20 & 1.23 & 54.72 & 53.58 & 1.21 & 1.15 & 0.61 & 0.58 & 17.14 & \begin{tabular}{|l|}
19.98 \\
\end{tabular} & 61.55 & 42.11 \\
\hline 11 & 1.13 & 1.17 & 57.36 & 55.85 & 1.35 & 1.26 & 0.64 & 0.60 & 17.74 & 20.57 & 55.09 & 56.54 \\
\hline 12 & 1.15 & 1.19 & 56.60 & 55.09 & 1.30 & 1.23 & 0.63 & 0.59 & 17.60 & 20.56 & 56.41 & 477.63 \\
\hline 13 & 1.20 & 1.23 & 54.72 & 53.58 & 1.21 & 1.15 & 0.61 & 0.57 & 17.06 & 19.85 & 62.48 & 43.40 \\
\hline Control & 1.31 & 1.36 & 50.57 & 48.68 & 1.02 & 0.95 & 0.52 & 0.49 & 15.30 & 17.99 & 67.00 & 37.75 \\
\hline
\end{tabular}




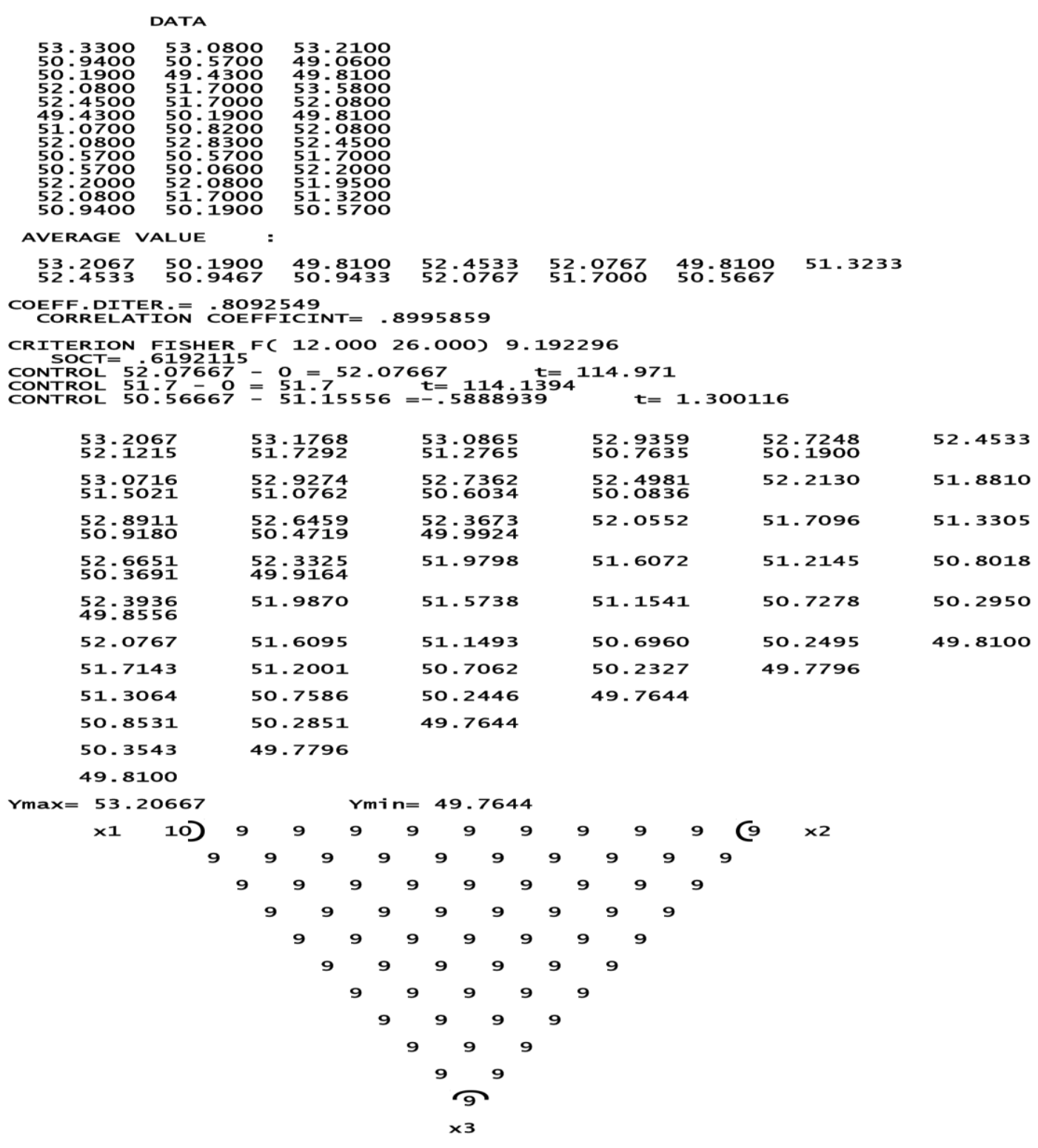

Fig (3): Total porosity (Db\%) in the surface soil layer $(0-20 \mathrm{~cm})$ as affected by all possible combinations of compost, nitrogen and phosphours in the first season.

Hydraulic conductivity data for 0 $20 \mathrm{~cm}$ soil depths in the first season are shown in Fig (4). The maximum kh value was $0.62 \mathrm{cmhr}^{-1}$ which obtained by number 10 that consists of $100 \%$ compost $\left(4.213\right.$ ton fed $\left.^{-1}\right)$ or $90 \%$ compost $+10 \%$ nitrogen $\left(3.972\right.$ ton $\mathrm{fed}^{-1}+7.5 \mathrm{~kg} \mathrm{~N}$ $\mathrm{fd}^{-1}$ ) in the first season. The numbers located on $\mathrm{X} 1 \mathrm{X} 2$ or $\mathrm{X} 1 \mathrm{X} 3$ sides obtain that, the interaction between $\mathrm{CN}$ and $\mathrm{CP}$ were more effective on increasing kh than NP. The results in Tables (2 and 3 ) and Fig. (4) cleared that, the compost application to soil led to improve soil hydrophysical properties. It might be due to the higher levels of water stable aggregates and more macro pore fraction leading to greater hydraulic conductivity. These results are in agreement with those of Keener et al. (2000), El-Sodany et al. (2009), Bandyopadhyay et al. (2010) and El-Maddah et al. (2012). 


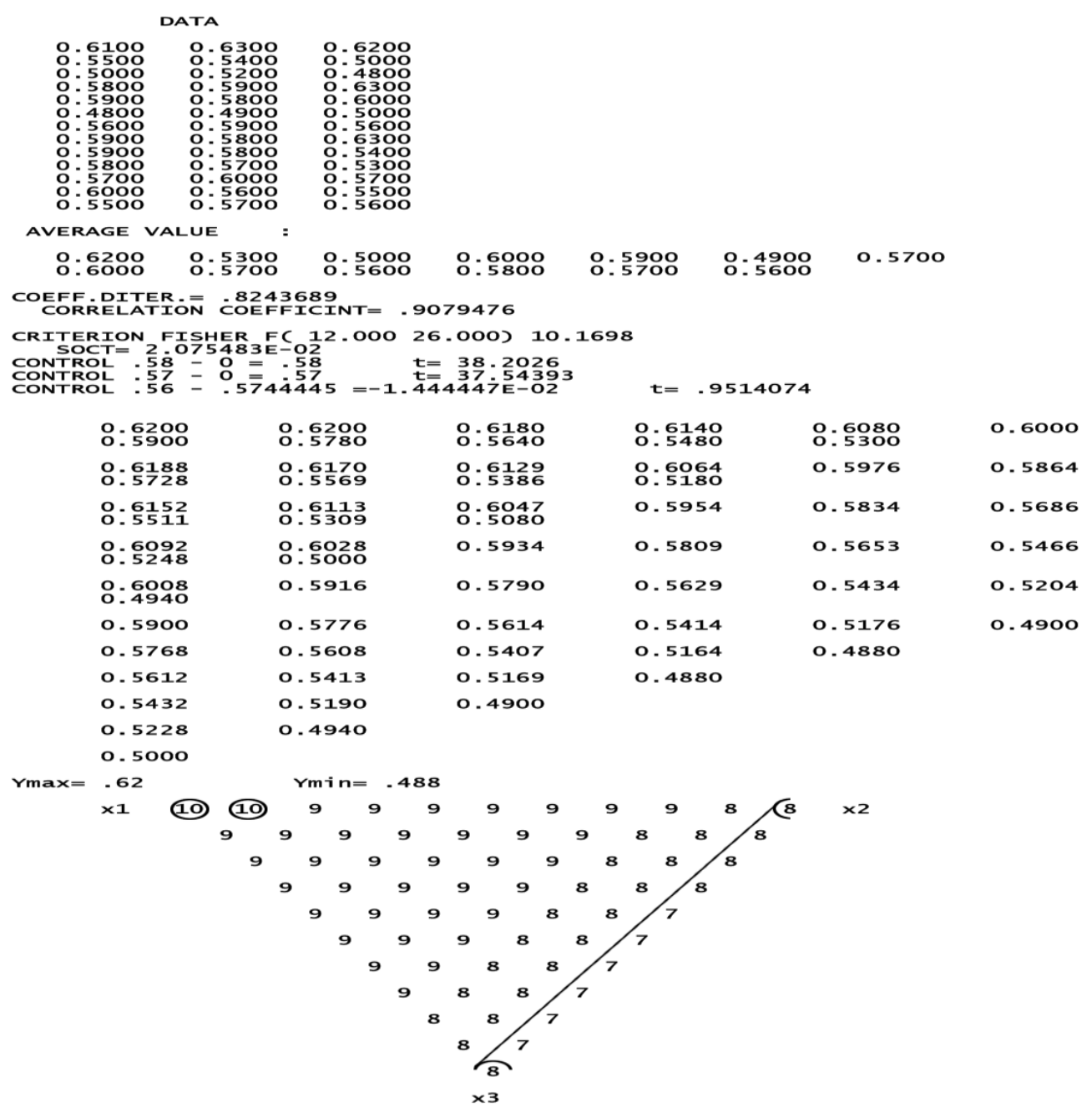

Fig (4): Hydraulic conductivity $\left(\mathrm{kh}, \mathrm{cmhr}^{-1}\right)$ in the surface soil layer $(0-20 \mathrm{~cm})$ as affected by all possible combinations of compost, nitrogen and phosphours in the first season.

\section{2- Water consumption (CU) and water use efficiency (WUE).}

The obtained results in Tables $(2$ and 3) indicated that, The lowest $\mathrm{CU}$ values were 30.40 and $50.23 \mathrm{~cm}$ decreased by 20.42 and $25.03 \%$ compared with the control in the first and second seasons, respectively. The lowest $\mathrm{CU}$ values were recorded with the single compost treatments (100\% compost) in the two seasons. On the other hand, the highest WUE value was $143.98 \mathrm{~kg} \mathrm{fed}^{-1} \mathrm{~cm}^{-1}$ and increased by $99.47 \%$ over the control in the first season, it was resulted by the treatment which consists of $50 \% \mathrm{C}$ and
$50 \% \mathrm{~N}$. Whereas, in the second season, the highest WUE value was $60.24 \mathrm{kgfed}^{-}$ ${ }^{1} \mathrm{~cm}^{-1}$ which increased by $59.58 \%$ over the control, it was recorded with the single compost treatment ( $100 \%$ compost).

The results in Figs. (5 and 6 ) showed the single effects of $C, N$ and $P$ on WUE, where these treatments gave 90,70 and $60 \%$ of the maximum WUE values equal to $136.88,108.62$ and $97.21 \mathrm{~kg} \mathrm{fed}^{-1} \mathrm{~cm}^{-1}$. The highest WUE was $146.24 \mathrm{~kg} \mathrm{fed}^{-1} \mathrm{~cm}^{-1}$ which obtained by number 10 which consists of $70 \%$ compost ( 2.949 ton fed $^{-1}$ ) and $30 \% \mathrm{~N}\left(22.50 \mathrm{~kg} \mathrm{~N}^{-1} \mathrm{fed}^{-1}\right)$ in the first season (Fig, 5). While, in the second 
season the single effects of $C, N$ and $P$ on WUE gave 90,70 and $60 \%$ of the maximum WUE values equal to 60.24 ,

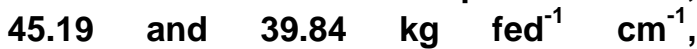
respectively. Whereas, the results in Fig. (6) obtain that, the highest WUE was $60.47 \mathrm{~kg} \mathrm{fed}^{-1} \mathrm{~cm}^{-1}$ which denoted by number 10 which consists of $90 \%$ C $\left(6.068\right.$ ton $\left.\mathrm{fed}^{-1}\right)+10 \% \mathrm{~N}\left(12 \mathrm{~kg} \mathrm{fed}^{-1}\right)$. Also, the numbers located on X1 X2, X1 $\mathrm{X} 3$ sides and inside triangle refer to positive interactions more than $\mathrm{X} 2 \mathrm{X} 3$ on water use efficiency (WUE) in the tow seasons (Figs, 5 and 6). From the results in Tables ( 2 and 3 ) and Figs. (5 and 6) noted that, the addition of $\mathrm{C}$ or $\mathrm{C}+\mathrm{N}$ to soil caused an increase in water use efficiency. These results may be due to the improve of soil physical and hydrophysical properties. Similar results were obtained by Bandyopadhyay et al. (2010) and Brown and Cotton (2011).

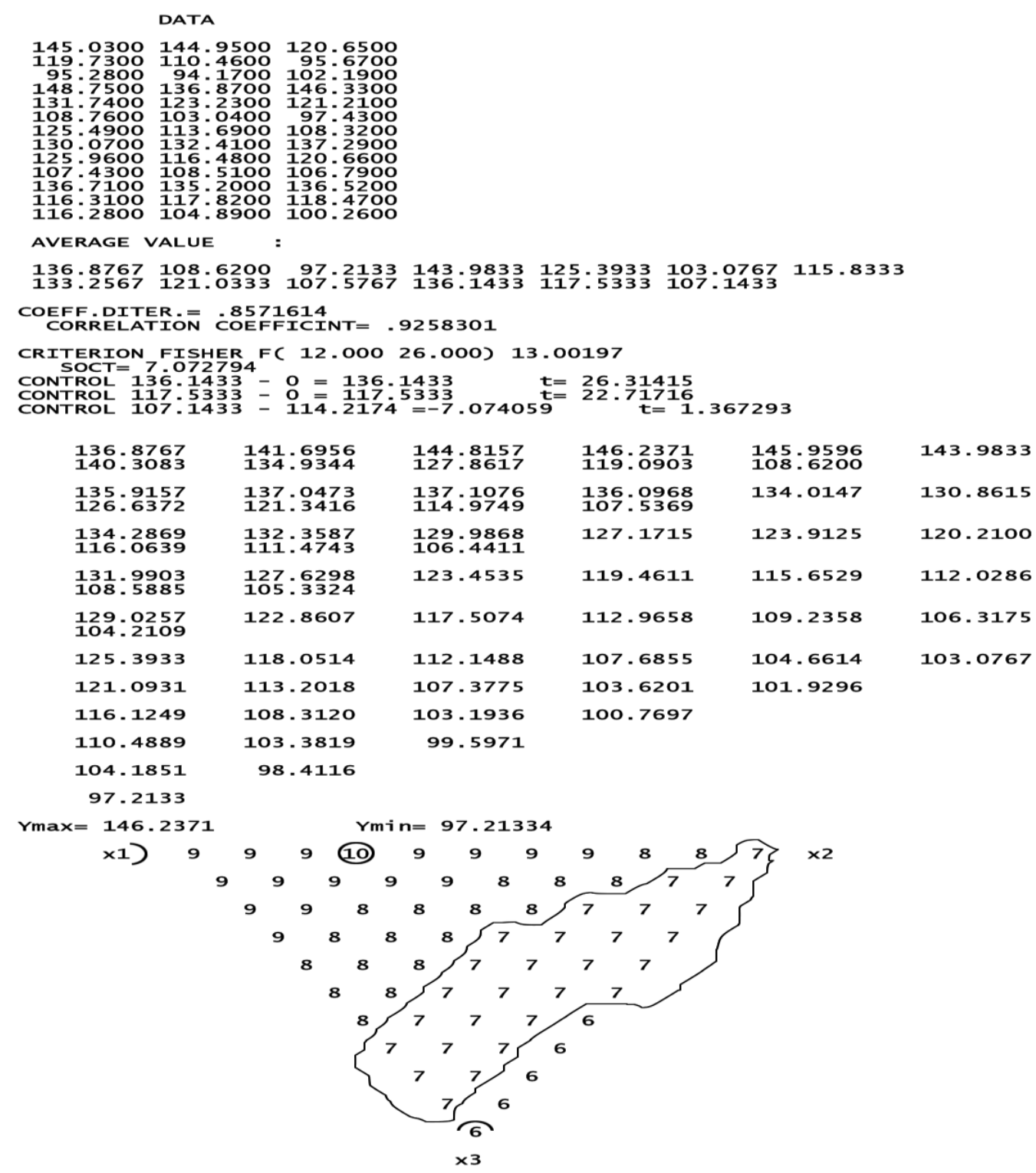

Fig (5): Water use efficiency (WUE, $\mathrm{kg} \mathrm{fed}^{-1} \mathrm{~cm}^{-1}$ ) as affected by all possible combinations of compost, nitrogen and phosphours in the first season. 


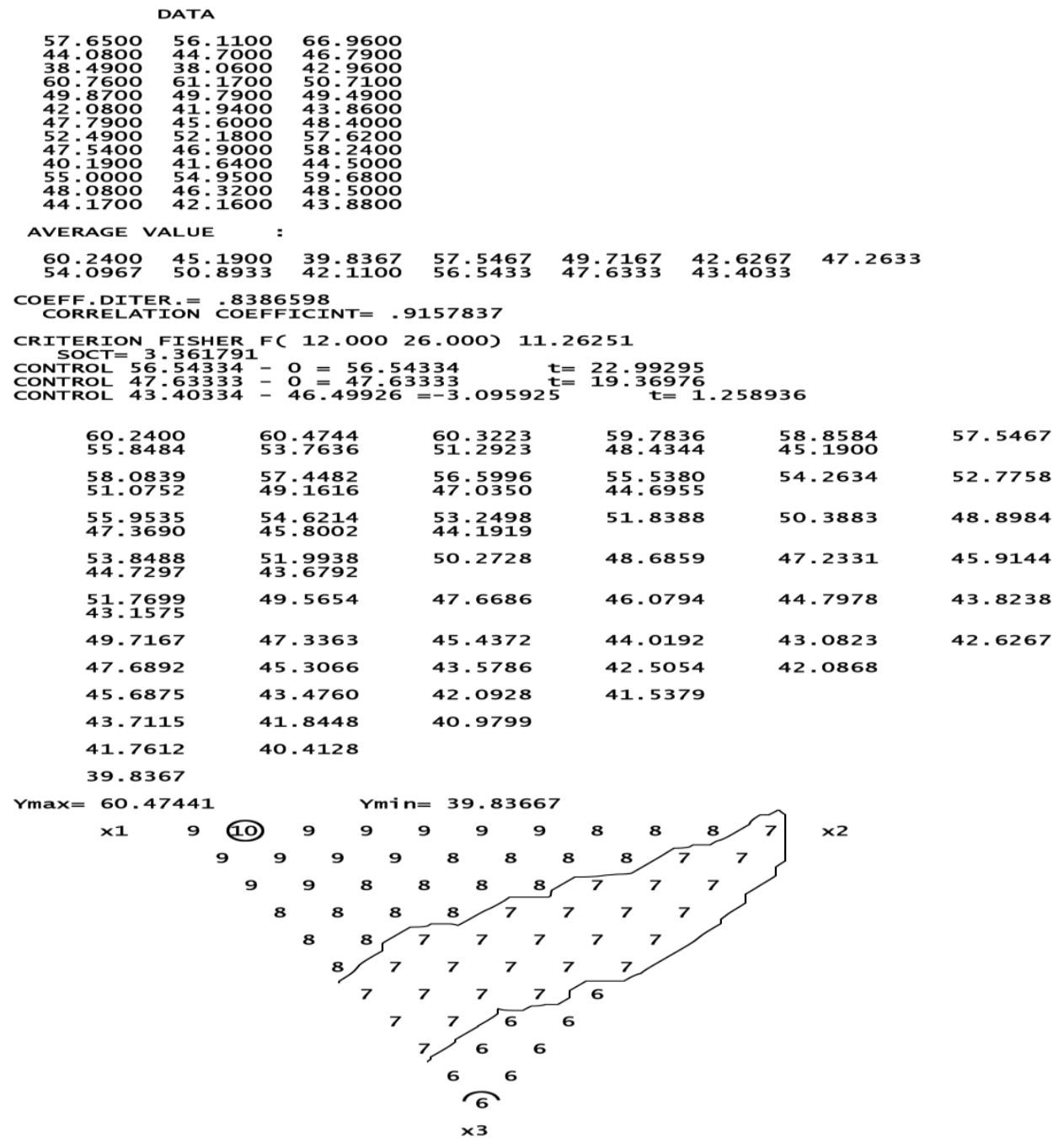

Fig (6): Water use efficiency (WUE,kg fed ${ }^{-1} \mathrm{~cm}^{-1}$ ) as affected by all possible combinations of compost, nitrogen and phosphours in the second season.

Effect of different treatments on some soil chemical properties.

1- Soil reaction $(\mathrm{pH})$ and electrical conductivity (EC)

The results in Tables (4 and 5$)$ indicated that, all treatments led to decrease in soil $\mathrm{pH}$ and increased soil EC at soil depths $0-20$ and $20-40 \mathrm{~cm}$ in the two seasons compared with the control. The lowest $\mathrm{pH}$ values were 7.34 and 7.32 which decreased by 5.17 and $6.63 \%$ compared to the control at the two soil depths, respectively in the first season
(Table, 4) and were 7.29 and 7.33 , where its decreased by 5.45 and $6.03 \%$ compared to the control at the tow soil depths, respectively in the second season (Table, 5). These results also show that, the plots were tested by the addition of $100 \%$ C gave the lowest $\mathrm{pH}$ values at the two soil depths in the two seasons. It might be due to organic acids resulting from compost decomposition. Similar results are in agreement with Liang et al. (2012) and Bharath et al. (2017). 
Table (4): Effect of different treatments on some soil chemical properties after wheat in the first season (winter 2018/2019)

\begin{tabular}{|c|c|c|c|c|c|c|c|c|c|c|c|c|c|c|}
\hline \multirow{3}{*}{ 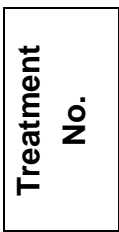 } & \multirow{2}{*}{\multicolumn{2}{|c|}{$\begin{array}{l}\text { pH, 1:2.5 } \\
\text { (soil: water } \\
\text { susp.) }\end{array}$}} & \multirow{2}{*}{\multicolumn{2}{|c|}{$\begin{array}{l}\mathrm{EC}, \mathrm{dSm}^{-1} \\
\text { (Soil paste } \\
\text { extract) }\end{array}$}} & \multicolumn{6}{|c|}{ Total macronutrients, \% } & \multirow{2}{*}{\multicolumn{2}{|c|}{$\begin{array}{c}\text { Organic } \\
\text { carbon, \% }\end{array}$}} & \multirow{2}{*}{\multicolumn{2}{|c|}{ C / $\mathrm{N}$ ratio }} \\
\hline & & & & & \multicolumn{2}{|r|}{$\mathbf{N}$} & & \multicolumn{2}{|r|}{$\mathrm{K}$} & & & & \\
\hline & $\begin{array}{l}0-20 \\
\mathrm{~cm}\end{array}$ & $\begin{array}{c}20-40 \\
\mathrm{~cm}\end{array}$ & $\begin{array}{c}0-20 \\
\mathrm{~cm}\end{array}$ & $\begin{array}{c}20-40 \\
\mathrm{~cm}\end{array}$ & $\begin{array}{c}0-20 \\
\mathrm{~cm} \\
\end{array}$ & & $\begin{array}{c}0-20 \\
\mathrm{~cm}\end{array}$ & $\begin{array}{c}20-40 \\
\mathrm{~cm}\end{array}$ & $\begin{array}{c}0-20 \\
\mathrm{~cm}\end{array}$ & $\begin{array}{c}20-40 \\
\mathrm{~cm}\end{array}$ & $\begin{array}{l}0-20 \\
\mathrm{~cm}\end{array}$ & $\begin{array}{c}20-40 \\
\mathrm{~cm}\end{array}$ & $\begin{array}{c}0-20 \\
\mathrm{~cm} \\
\end{array}$ & $\begin{array}{c}20-40 \\
\mathrm{~cm}\end{array}$ \\
\hline 1 & & & & .56 & 0.160 & & 0.045 & & & 0.371 & 1.814 & 1.579 & 11.34 & \\
\hline 2 & & & & 38 & 64 & & 042 & & 57 & 340 & 1.638 & 1.423 & .99 & \\
\hline 3 & & & & 86 & 148 & & 059 & 54 & 354 & 336 & 1.622 & 1.409 & 10.96 & 10.36 \\
\hline 4 & & & & & & & & & & 360 & 1.778 & .535 & 1.11 & 0.51 \\
\hline 5 & & & & & 150 & & & & & .358 & & 1.516 & & 0.99 \\
\hline 6 & & & & & 151 & 139 & 053 & 0.049 & 0.351 & 0.332 & 1.605 & 1.394 & 0.63 & 10.03 \\
\hline 7 & & & & 03 & 154 & & 049 & & 364 & 0.348 & 1.692 & 1.474 & \begin{tabular}{|l|}
10.99 \\
\end{tabular} & 10.31 \\
\hline 8 & & & & & & & & & & & & & & 10.58 \\
\hline 9 & & & & & 158 & 0.145 & 0.047 & 0.043 & 0.363 & 0.345 & 1.678 & 1.463 & 10.62 & 10.09 \\
\hline 10 & & & & & 149 & & 054 & 050 & 361 & 0.344 & 1.666 & 1.450 & 1.18 & 10.58 \\
\hline 11 & & & 2.00 & & .159 & 0.145 & 0.046 & 0.042 & 0.371 & 0.356 & 1.736 & 1.512 & 10.92 & 10.43 \\
\hline 12 & & & & & & & & & & & 1.720 & 1.500 & 11.32 & 10.7 \\
\hline 13 & & & & & & & & & & & & & 10.80 & 10.18 \\
\hline ontrol & 7.74 & .84 & 2.34 & 2.75 & 0.137 & 0.134 & 0.041 & 0.038 & 0.348 & 0.331 & 1.412 & 1.379 & 10.31 & 10.29 \\
\hline
\end{tabular}

Table (5): Effect of different treatments on some soil chemical properties after maize in the second season (summer 2019).

\begin{tabular}{|c|c|c|c|c|c|c|c|c|c|c|c|c|c|c|}
\hline \multirow{3}{*}{ 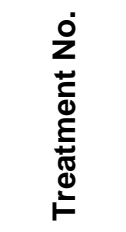 } & \multirow{2}{*}{\multicolumn{2}{|c|}{$\begin{array}{c}\text { pH, 1:2.5 } \\
\text { (soil: water } \\
\text { susp.) }\end{array}$}} & \multirow{2}{*}{\multicolumn{2}{|c|}{$\begin{array}{c}\mathrm{EC}, \mathrm{dSm}^{-1} \\
\text { (Soil paste } \\
\text { extract) }\end{array}$}} & \multicolumn{6}{|c|}{ Total macronutrients, \% } & \multirow{2}{*}{\multicolumn{2}{|c|}{$\begin{array}{c}\text { Organic } \\
\text { carbon, \% }\end{array}$}} & \multirow{2}{*}{\multicolumn{2}{|c|}{$\mathrm{C} / \mathrm{N}$ ratio }} \\
\hline & & & & & \multicolumn{2}{|c|}{$\mathbf{N}$} & & & & & & \\
\hline & $\begin{array}{c}0-20 \\
\mathrm{~cm}\end{array}$ & $\begin{array}{c}20-40 \\
\mathrm{~cm}\end{array}$ & \begin{tabular}{|c|}
$0-20$ \\
cm
\end{tabular} & $\begin{array}{c}20-40 \\
\mathrm{~cm}\end{array}$ & \begin{tabular}{|c|}
$0-20$ \\
cm
\end{tabular} & $\begin{array}{c}20-40 \\
\mathrm{~cm}\end{array}$ & \begin{tabular}{|c|}
$0-20$ \\
$\mathrm{~cm}$
\end{tabular} & $\begin{array}{c}20-40 \\
\mathrm{~cm}\end{array}$ & $\begin{array}{c}0-20 \\
\mathrm{~cm}\end{array}$ & $\mid \begin{array}{c}20-40 \\
\mathrm{~cm}\end{array}$ & $\begin{array}{c}0-20 \\
\mathrm{~cm}\end{array}$ & \begin{tabular}{|c|}
$20-40$ \\
$\mathrm{~cm}$
\end{tabular} & \begin{tabular}{c|}
$0-20$ \\
$\mathrm{Cm}$
\end{tabular} & $\begin{array}{c}20-40 \\
\mathrm{~cm}\end{array}$ \\
\hline 1 & 720 & & & 3.65 & 0.163 & 0.149 & 0.049 & 0.045 & 0.396 & 0.388 & 1.798 & 1.585 & 11.03 & 10.64 \\
\hline 2 & & & 51 & 2.96 & 168 & 0.154 & 046 & 043 & 0.368 & 0.351 & 1.622 & 427 & 9.65 & 9.27 \\
\hline 3 & & & & 2.95 & 152 & 0.139 & 069 & 0.059 & 0.365 & 0.348 & 1.607 & 1.410 & 10.57 & 10.14 \\
\hline 4 & & & & 34 & 164 & 50 & 047 & 44 & 386 & 369 & 1.753 & 537 & 10.69 & 0.25 \\
\hline 5 & & & & 3.33 & 154 & 0.141 & 0.057 & 0.054 & 0.384 & 0.368 & 1.733 & 1.563 & 11.25 & 11.09 \\
\hline 6 & & & & 82 & 155 & & 057 & & 0.361 & 0.345 & 1.593 & 1.396 & 10.28 & 9.83 \\
\hline 7 & & & & 3.12 & 158 & 0.145 & 0.053 & 0.050 & 0.381 & 0.358 & 1.678 & 1.476 & 10.62 & 10.18 \\
\hline 8 & & & & 3.33 & 161 & 0.147 & 0.052 & 0.049 & 0.385 & 0.368 & 1.741 & 1.524 & 10.81 & 10.37 \\
\hline 9 & & & & 3.05 & 0.162 & 0.148 & 0.051 & 0.047 & 0.376 & 0.356 & 1.667 & 1.465 & \begin{tabular}{|l|}
10.29 \\
\end{tabular} & 9.90 \\
\hline 10 & & & 59 & 2.98 & 0.153 & 0.140 & 0.058 & 0.055 & 0.374 & 0.355 & 1.652 & 1.450 & 10.80 & 10.36 \\
\hline 11 & & & & 3.30 & 0.163 & 0.148 & 0.050 & 0.046 & 0.383 & 0.365 & 1.720 & 1.510 & 10.55 & 10.20 \\
\hline 12 & & 7.4 & 1 & 3.18 & 0.159 & 0.143 & 0.057 & 0.053 & 0.381 & 0.363 & 1.707 & \begin{tabular}{|l|}
1.498 \\
\end{tabular} & 10.74 & 10.48 \\
\hline 13 & & 7.5 & 2.54 & 2.97 & 0.157 & 0.144 & 0.055 & 0.052 & 0.371 & 0.353 & 1.640 & 1.438 & 10.45 & 9.99 \\
\hline ontrol & 7.71 & 7.80 & 2.37 & 2.79 & 0.151 & 0.138 & 0.044 & 0.042 & 0.357 & 0.342 & 1.580 & 1.384 & 10.46 & 10.03 \\
\hline
\end{tabular}


Concerning soil electrical conductivity (EC). The lowest EC values in the first growing season were 2.38 and 2.78 ds $\mathrm{m}^{-1}$ increased by 1.71 and $1.09 \%$ over the control at the soil depths of $\mathbf{0 - 2 0}$ and 20 $40 \mathrm{~cm}$, respectively and were 2.39 and $2.82 \mathrm{ds} \mathrm{m}^{-1}$ increased by 0.84 and $1.08 \%$ over the control at the same depths in the second season. These increases in soil EC values may be attribute to high content of soluble cations and anions as shown in Tables (1-a and 1-b). Similar results were obtained by Liang et al. (2012) and Mahmood et al. (2017).

Data in Fig (7) clarified that, the individual applications of $\mathrm{C}, \mathrm{N}$ and $\mathrm{P}$ gave
100,80 and $70 \%$ of the maximum EC values which equal to $3.03,2.44$ and 2.41 $\mathrm{dSm}^{-1}$, respectively. Meanwhile, the highest EC values was $3.03 \mathrm{dSm}^{-1}$ which denoted by number 10 consists of $100 \%$ $C$, it was also observed that, the numbers located on X1 X2 and X1 X3 sides and inside triangle refer to the positive interactions of the studied treatments on increasing EC values more than X2 X3. These results mean that, the addition of $\mathrm{C}$ increased soil salinity more than $\mathrm{N}$ or P. It might be due to the high amount of dissolved salts in compost (Table, 1-b). Similar results were confirmed by Jinwei and Lianren (2011) and Almaz et al. (2017).

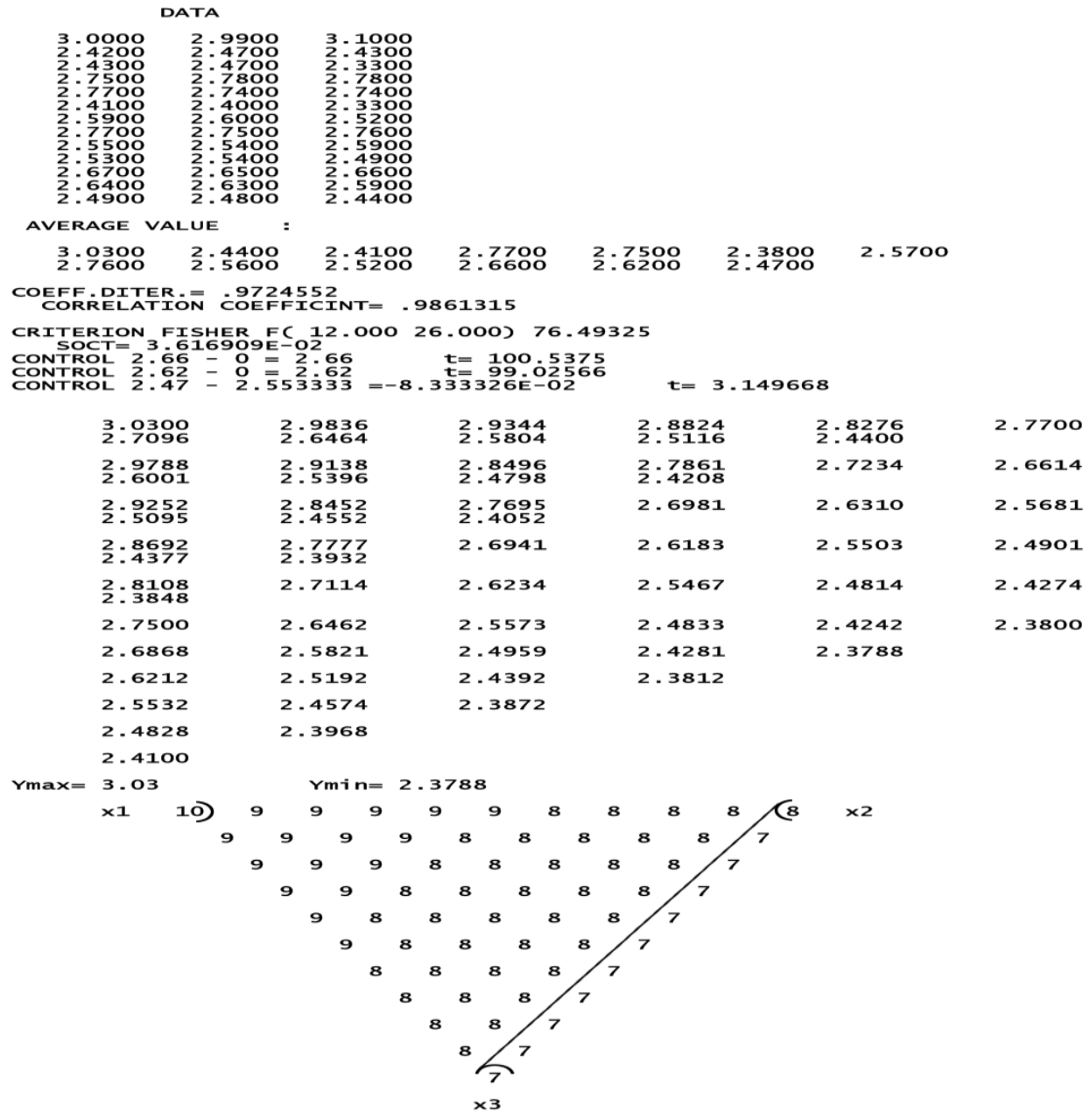

Fig (7): Electrical conductivity $\left(E C, \mathrm{dsm}^{-1}\right)$ in the surface soil layer $(0-20 \mathrm{~cm})$ as affected by all possible combinations of compost, nitrogen and phosphours in the first season. 


\section{2- Soil content of total macronutrients (NPK).}

The results in Tables (4 and 5 ) cleared that, all treated plots individually by $\mathrm{C}, \mathrm{N}$ and $P$ and in combinations increased the soil content of total NPK at $0-20$ and 20$40 \mathrm{~cm}$ soil depths in the first and second seasons compared with control. The highest content of total $\mathbf{N}$ were 0.164 and $0.149 \%$ at the two soil depths, respectively in the first season and were 0.168 and $0.154 \%$ at the same depths in the second season. Whereas, the highest content of total $\mathbf{P}$ were 0.059 and $0.054 \%$ at the two soil depths, respectively in the first season and were 0.069 and $0.059 \%$ at the same depths in the second season. The highest content of total $\mathrm{K}$ were $\mathbf{0 . 3 8 6}$ and $0.371 \%$ at the two soil depths, respectively in the first season and were 0.396 and $0.388 \%$ at the same depths in the second season. From the previous results may be noticed that, the highest content of total $\mathrm{N}, \mathrm{P}$ and $\mathrm{K}$ were recorded with the individual treatments $(100 \% \mathrm{~N}$, $100 \% \mathrm{P}$ and $100 \% \mathrm{C}$ ) respectively at the two soil depths in the two seasons. These results could be attributed to the ability of additional treatments to supply nutrients and improvement the physical and chemical properties of the soil and the ability of compost to release nutrients gradually throughout the growing season. These results are supported by the work of Adugna (2016), Bharath et al. (2017) and Mahmood et al. (2017).

\section{3- Organic carbon (O.C) and $\mathrm{C} / \mathrm{N}$ ratio.}

The obtained results in Tables (4 and 5) showed that, the highest O.C content were 1.814 and $1.579 \%$ recorded increase percent by 41.06 and $14.5 \%$ over the control at $0-20$ and $20-40 \mathrm{~cm}$ soil depths, respectively in the first season (Table, 4) and were 1.798 and $1.585 \%$ which increased by 13.80 and $14.52 \%$ over the control at the two soil depths, respectively (Table, 5) in the second season. It can be noted that, the individual compost treatment $(100 \%$ compost) gave the highest O.C content. This result might be due to compost contents higher content of organic matter and the retention of dissolved organic mater leading to change in $\mathbf{0 . C} \%$ in soil. These results are in line with those reported by Keener et al. (2000), MoyinJesu (2015) and Mahmood et al. (2017).

Data in Fig (8) show that, the effects of individual treatments of $\mathbf{C}, \mathbf{N}$ and $\mathbf{P}$ gave 90, 90 and $80 \%$ of the maximum O.C content which equal to 1,184, 1.638 and $1.622 \%$, respectively. These results mean that $C$ was effective upon O.C increase more than $\mathbf{N}$ and $\mathbf{P}$ which took the order C $>\mathrm{N}>\mathrm{P}$. While, the highest O.C content was $1.815 \%$ which denoted by number 10 which consists of $90 \%$ C $\left(3.792\right.$ ton fed ${ }^{-1}+10 \% N\left(7.50 \mathrm{~kg} \mathrm{~N} \mathrm{fed}^{-1}\right)$ in the first season.

Concerning, $\mathrm{C} / \mathrm{N}$ ratio, the results in Tables (4 and 5) cleared that, the maximum $\mathrm{C} / \mathrm{N}$ ratio values were 11.65 and 10.99 at the $0-20$ and $20-40 \mathrm{~cm}$ soil depths, respectively in the first season and were 11.25 and 11.09 at the same depths in the second season. It recorded under the treatment consist of $50 \% \mathrm{C}+$ $50 \% \quad P$ in the two seasons. Data presented in Fig (9) denoted that, the effects of the three individual treatments of $\mathrm{C}, \mathrm{N}$ and $\mathrm{P}$ gave 90,80 and $90 \%$ of the maximum $\mathrm{C} / \mathrm{N}$ ratio values which equal to 11.34, 9.99 and 10.96, respectively. On the other hand the highest $\mathrm{C} / \mathrm{N}$ ratio was 11.67 obtained by number 10 which consists of $60 \% \mathrm{C}+40 \% \mathrm{P}$ in the first season. This might be due to higher accumulation of $\mathbf{C}$ in soil in comparison to $\mathbf{N}$. Similar conclusion were obtained by El-Sodany et al. (2009), Bandyopadhyay et al. (2010), El-Maddah et al. (2012), Almaz et al. (2017) and Mahmood et al. (2017) .

\section{Effect of different treatments on yield and yield components.}

The results in Tables (6 and 7) indicated that, growth characters and 
yield of wheat and maize plants increased with all the individually additions of $\mathbf{C}, \mathbf{N}$ and $\mathbf{P}$ and in combinations compared with the control, where the highest grain yield of wheat was 4.380 ton $^{-1} \mathrm{fed}^{-1}$ with relative increase yield (R.I.Y) of $58.85 \%$ over the control, also the highest straw yield of wheat was 4.471 ton fed $^{-1}$ with (R. I. Y) of $41.98 \%$ over the control, (Table, 6). While, the highest maize grain yield was 3.127 ton fed $^{-1}$ by (R.I.G.Y) of $23.62 \%$ over the control, (Table ,7). From the results in Tables ( 6 and 7 ) may be noted that, the highest growth characters and grain yield of wheat and maize were recorded with the treatment consists of $50 \% \mathrm{C}+50 \% \mathrm{~N}$. The recorded results in Figs. (10 and 11) showed that, the effect of the individual treatments of $\mathrm{C}, \mathrm{N}$ and $\mathrm{P}$ gave $\mathbf{9 0 . 9 0}$ and
$80 \%$ of the maximum grain yield for wheat and maize, respectively. Whereas, the highest grain yields were 4.385 and 3.134 ton fed $^{-1}$ for wheat and maize, respectively obtained by number 10 which consists of $60 \% \mathrm{C}+40 \% \mathrm{~N}$. Increasing in grain and straw yields from the combined application of compost and nitrogen could be attributed to better crop growth, due to the readily available nutrients from the inorganic fertilizers sources and controlled release of nutrients from compost. Also, the positive effect of compost in preventing lose of nutrients from mineral fertilizers. These results are in agreement with these cleared by Jinwei and Lianren (2011), Ahmad et al. (2013), Gomaa et al. (2015) and Chopra et al. (2016).

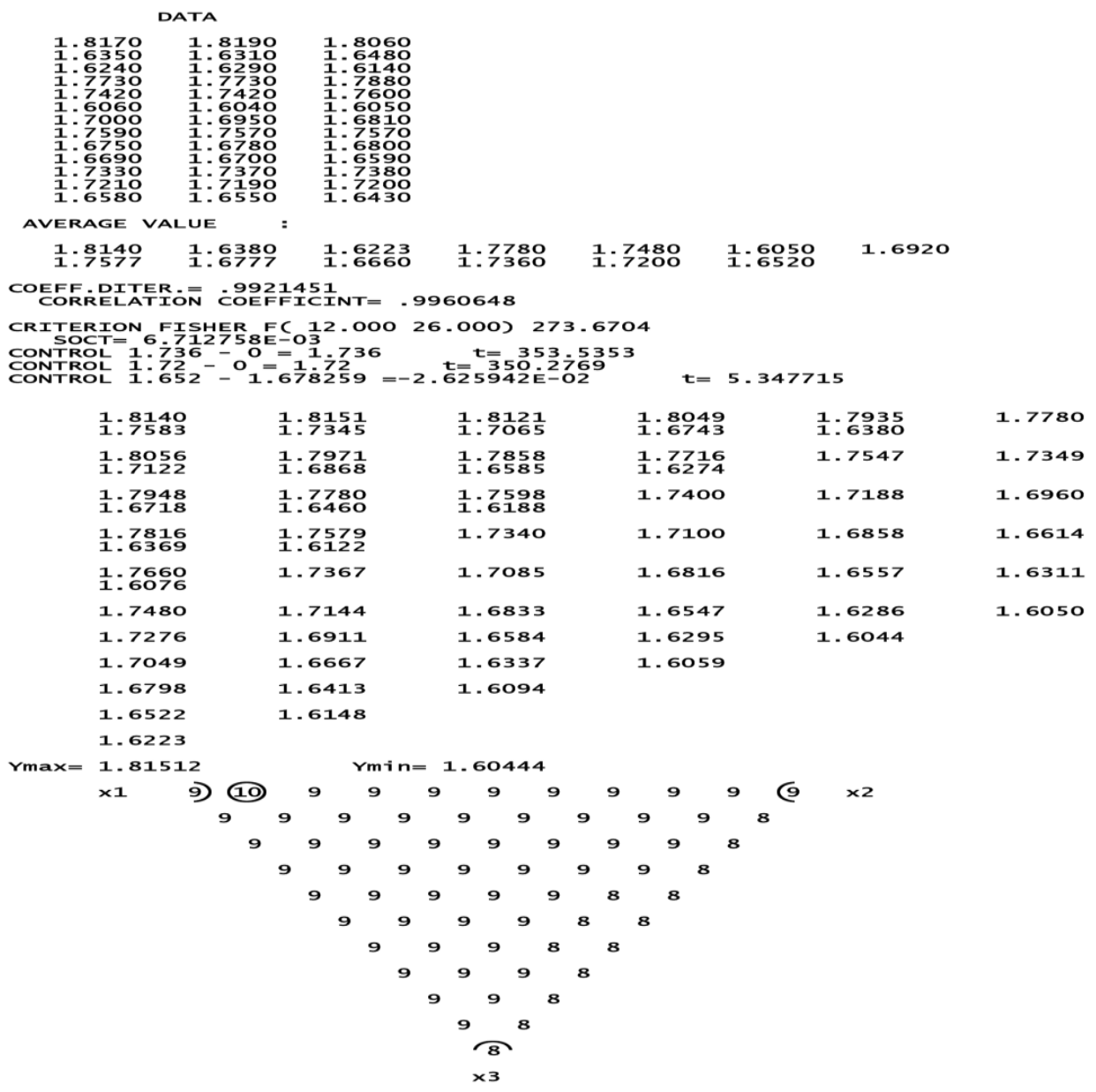

Fig (8): Organic carbon (O.C\%) in the surface soil layer $(0-20 \mathrm{~cm})$ as affected by all possible combinations of compost, nitrogen and phosphours in the first season. 


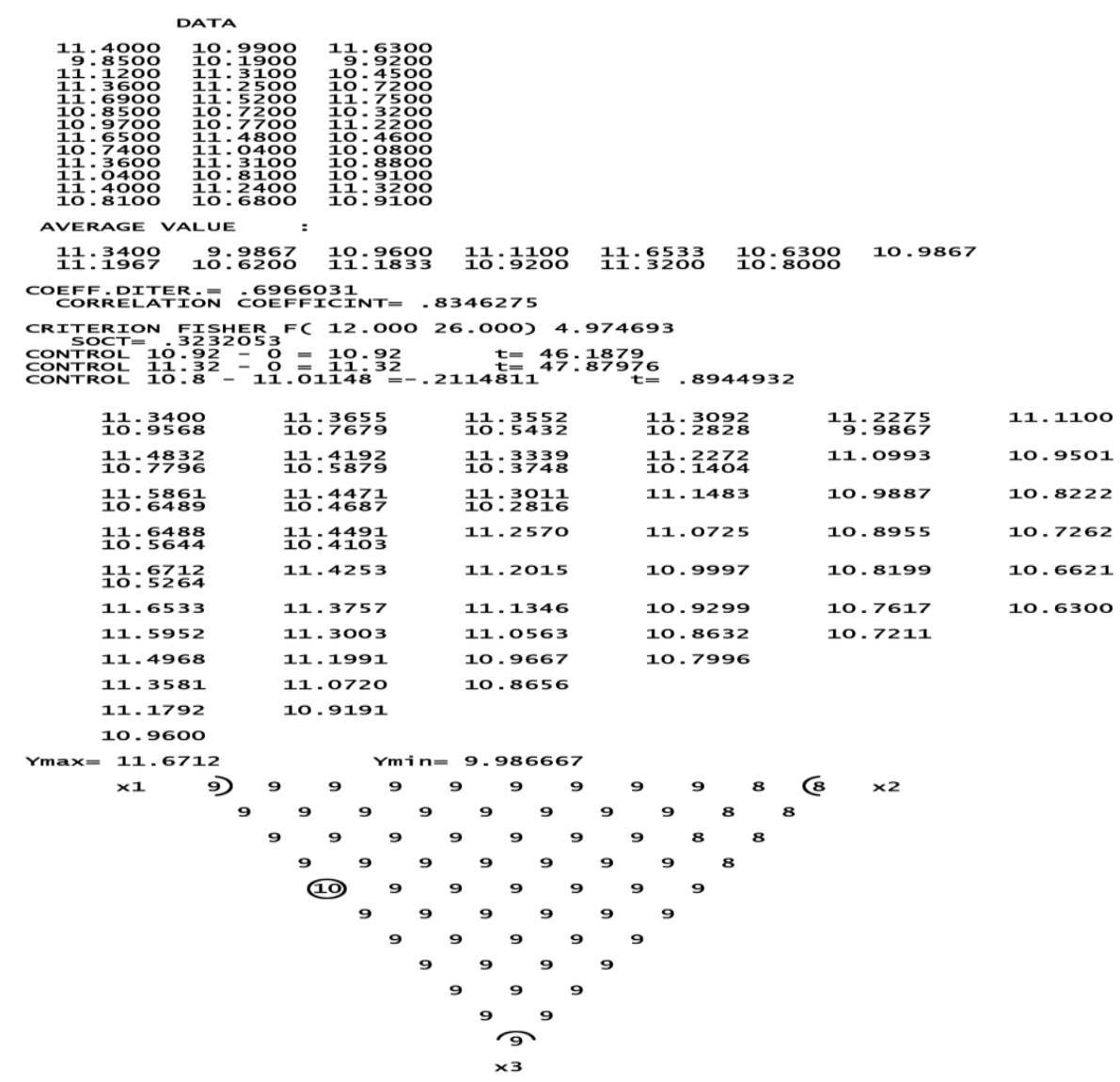

Fig (9): $\mathrm{C} / \mathrm{N}$ ratio in the surface soil layer $(0-20 \mathrm{~cm})$ as affected by all possible combinations of compost, nitrogen and phosphours in the first season.

Table (6): Effect of different treatments on wheat yield and some growth characters in the first season (winter 2018/2019)

\begin{tabular}{|c|c|c|c|c|c|c|c|c|c|c|}
\hline \multirow{2}{*}{ 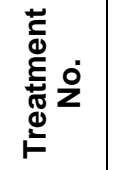 } & \multirow{2}{*}{$\begin{array}{l}\text { Biological } \\
\text { yield Ton } \\
\text { fed }^{-1}\end{array}$} & \multirow{2}{*}{$\begin{array}{l}\text { Grain } \\
\text { yield } \\
\text { Ton } \\
\text { fed }^{-1}\end{array}$} & \multirow{2}{*}{$\begin{array}{c}\text { Straw } \\
\text { yield } \\
\text { Ton fed }^{-1}\end{array}$} & \multirow{2}{*}{$\begin{array}{c}\text { Plant } \\
\text { height, } \\
\text { cm }\end{array}$} & \multirow{2}{*}{$\begin{array}{c}\text { Spike } \\
\text { length } \\
\mathrm{cm}\end{array}$} & \multirow{2}{*}{$\begin{array}{c}1000 \\
\text { Seed } \\
\text { weight, } g\end{array}$} & \multirow{2}{*}{$\begin{array}{c}\text { Dry matter } \\
\text { g/10 plants } \\
\text { after } \\
90 \text { days }\end{array}$} & \multicolumn{2}{|c|}{${ }^{*}$ R.I.Y., \% } & \multirow{2}{*}{$\begin{array}{l}\text { Harvest } \\
\text { Index,\% }\end{array}$} \\
\hline & & & & & & & & Grain & Straw & \\
\hline 1 & 8.4770 & 1611 & 4.3159 & 102.67 & 12.59 & .53 & 98 & 50.91 & 37.04 & 49.09 \\
\hline 2 & 8.2880 & .9885 & 4.2995 & 100.86 & 12.16 & 75.41 & 24.89 & 44.65 & 36.52 & 48.12 \\
\hline 3 & 7.5636 & 6075 & 3.9561 & 94.03 & 11.27 & 60.89 & 20.28 & 30.83 & 25.61 & 47.70 \\
\hline 4 & 8.8514 & 3800 & 4.4714 & 104.29 & 12.69 & 80.71 & 38.83 & 58.85 & 41.98 & 49.48 \\
\hline 5 & & & & & 11.97 & & & & 56 & \\
\hline 6 & 8.0406 & 3.8952 & 4.1454 & 99.81 & 12.08 & 72.63 & 23.79 & 41.27 & 31.63 & 48.44 \\
\hline 7 & 8.1692 & .9037 & 4.2655 & 100.17 & 12.10 & 74.43 & 24.19 & 41.58 & 35.44 & 47.79 \\
\hline 8 & 8.3225 & 4.0537 & 4.2688 & 101.47 & 12.23 & 75.66 & 25.32 & 47.02 & 35.54 & 48.71 \\
\hline 9 & 8.3816 & 4.1091 & 4.2725 & 101.99 & 12.41 & 76.77 & 26.33 & 49.03 & 35.66 & 49.02 \\
\hline 10 & 7.7657 & 3.7586 & 4.0071 & 95.80 & 11.66 & 63.01 & 21.52 & 36.31 & 27.23 & 48.40 \\
\hline 11 & 8.7863 & 4.3321 & 4.4542 & 103.03 & 12.63 & 78.50 & 30.30 & 57.11 & 41.43 & 49.31 \\
\hline 12 & 7.8441 & 3.7788 & 4.0653 & 96.88 & 11.84 & 65.01 & 22.37 & 37.05 & 29.08 & 48.17 \\
\hline 13 & 7.8997 & 3.8454 & 4.0543 & 97.45 & 11.91 & 68.71 & 22.95 & 39.46 & 28.73 & 48.68 \\
\hline Contro & 5.9067 & 2.7573 & 3.1494 & 92.69 & 10.85 & 60.21 & 20.12 & 0.00 & 0.00 & 46.68 \\
\hline
\end{tabular}

* relative increasing yield 
Table (7): Effect of different treatments on maize yield and some growth characters in the second season (summer 2019)

\begin{tabular}{|c|c|c|c|c|c|c|c|c|c|}
\hline & & & & & & & & & \\
\hline 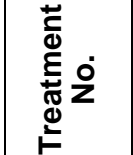 & $\begin{array}{l}\text { Plant } \\
\text { height, } \\
\text { cm }\end{array}$ & $\begin{array}{l}\text { Ear } \\
\text { length, } \\
\text { cm }\end{array}$ & $\begin{array}{c}\text { Ear } \\
\text { diameter, } \\
\text { cm }\end{array}$ & $\begin{array}{c}\text { No. of } \\
\text { rows } \\
\text { per ear }\end{array}$ & $\begin{array}{c}\text { No. of } \\
\text { kernels } \\
\text { per } \\
\text { row }\end{array}$ & $\begin{array}{l}100 \text { seed } \\
\text { weight, g }\end{array}$ & $\begin{array}{l}\text { Dry matter, } \\
\text { g/plant after } \\
80 \text { days }\end{array}$ & $\begin{array}{c}\text { Grain } \\
\text { yield } \\
\text { Ton fed }^{-1}\end{array}$ & **R.I.G.Y. \\
\hline 1 & 228.25 & 20.25 & 7.77 & 14.18 & 42.80 & 40.53 & 196.35 & 3.0257 & 19.63 \\
\hline 2 & 223.11 & 19.78 & 7.61 & 13.67 & 41.63 & 38.69 & 176.80 & 2.8840 & 14.03 \\
\hline 3 & 198.66 & 18.17 & 6.91 & 12.83 & 36.73 & 33.74 & 150.47 & 2.5530 & 0.94 \\
\hline 4 & 232.50 & 21.17 & 7.86 & 14.76 & 45.07 & 41.79 & 226.77 & 3.1265 & 23.62 \\
\hline 5 & 218.47 & 19.30 & 7.42 & 13.43 & 40.59 & 37.16 & 163.58 & 2.7383 & 8.27 \\
\hline 6 & 219.75 & 19.48 & 7.51 & 13.55 & 40.86 & 37.73 & 168.51 & 2.7700 & 9.52 \\
\hline 7 & 220.44 & 19.65 & 7.53 & 13.63 & 41.08 & 38.27 & 171.58 & 2.7839 & 10.07 \\
\hline 8 & 223.94 & 19.99 & 7.66 & 13.91 & 42.08 & 39.29 & 186.83 & 2.9796 & 17.81 \\
\hline 9 & 225.10 & 20.11 & 7.71 & 14.08 & 42.24 & 39.49 & 194.33 & 3.0072 & 18.90 \\
\hline 10 & 204.43 & 18.60 & 7.14 & 13.01 & 37.98 & 35.66 & 154.40 & 2.5920 & 2.48 \\
\hline 11 & 229.04 & 20.50 & 7.83 & 14.33 & 43.95 & 40.79 & 209.82 & 3.1148 & 23.15 \\
\hline 12 & 214.12 & 18.98 & 7.23 & 13.07 & 38.99 & 36.07 & 158.44 & 2.6870 & 6.24 \\
\hline 13 & 218.03 & 19.21 & 7.35 & 13.38 & 39.67 & 36.45 & 160.39 & 2.7119 & 7.22 \\
\hline ontrol & 165.56 & 14.83 & 5.85 & 10.14 & 28.28 & 30.05 & 126.96 & 2.5292 & 0.00 \\
\hline
\end{tabular}

${ }^{* *}$ relative increasing grain yield

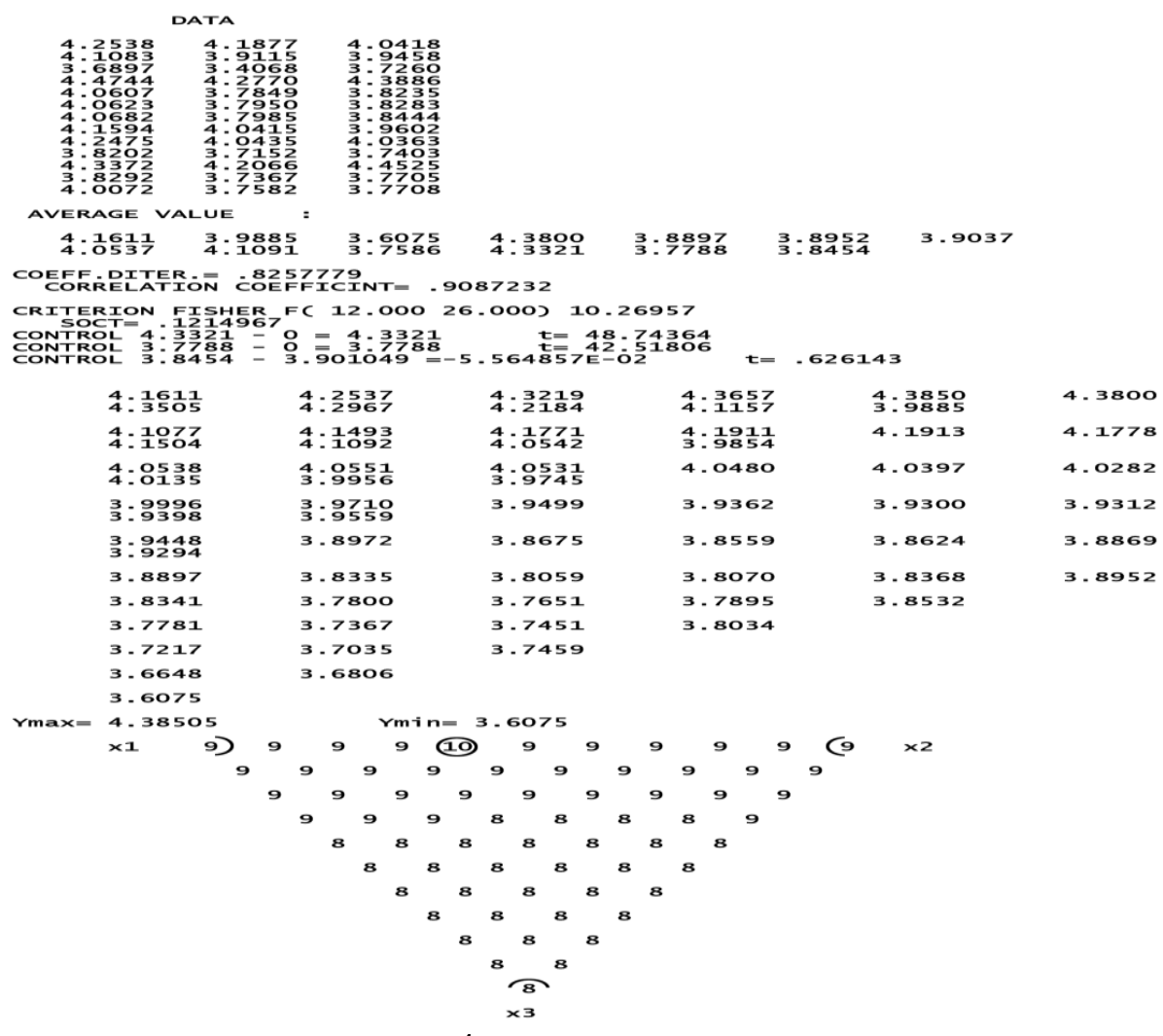

Fig (10): Wheat grain yield (ton fed $^{-1}$ ) as affected by all possible combinations of compost, nitrogen and phosphours in the first season. 


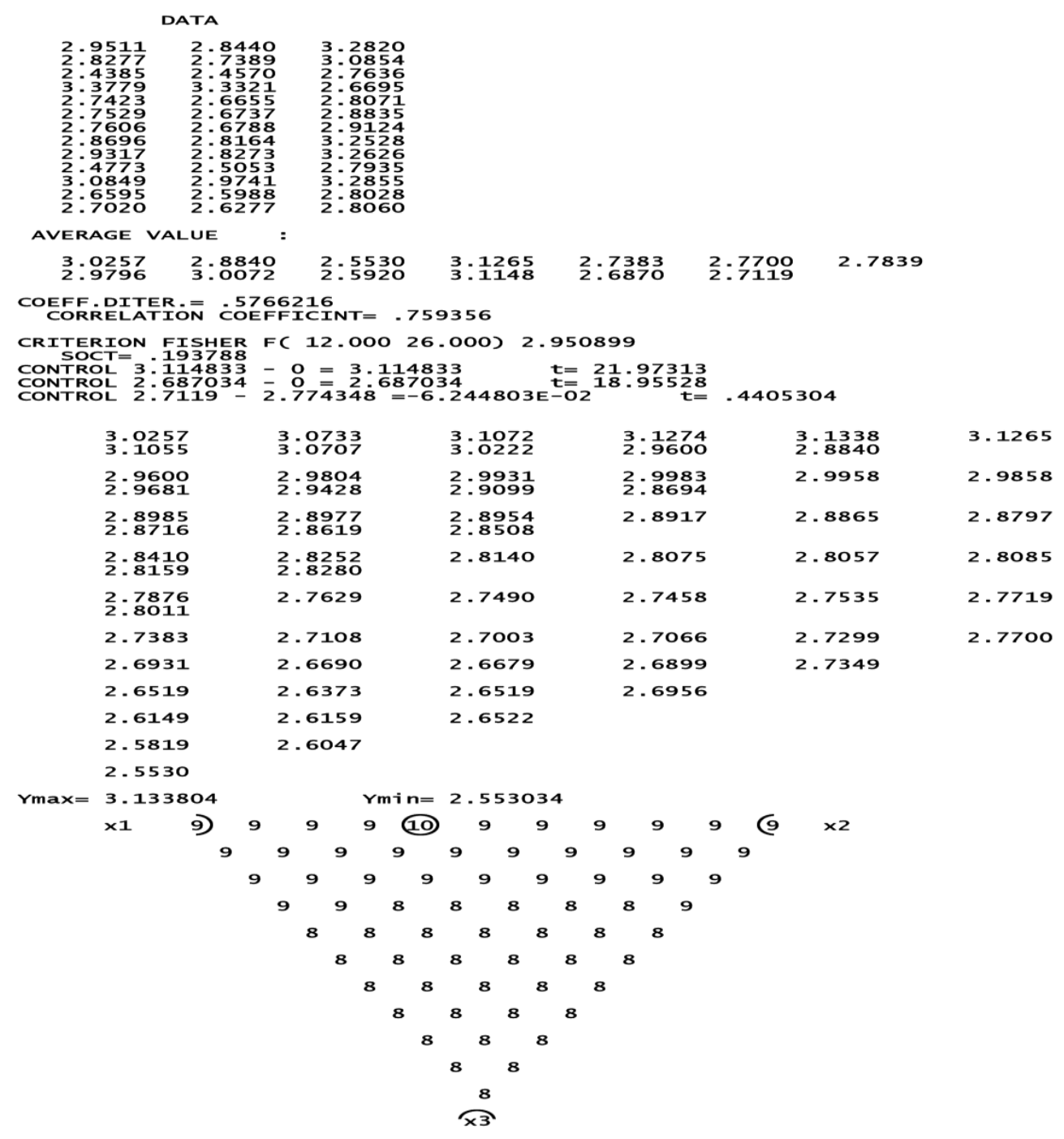

Fig (11): Maize grain yield (ton fed ${ }^{-1}$ ) as affected by all possible combinations of compost, nitrogen and phosphours in the second season.

\section{Economical analysis.}

Data in Tables ( 8 and 9 ) show the total inputs costs, outputs and net revenue for the actual thirteen treatments besides the control. It can be noticed from Table (9) that, the highest net revenue (7636.84 LE fed $^{-1}$ ) was recorded by using the treatment consists of $50 \% \mathrm{C}+\mathbf{5 0 \%} \mathrm{N}$ in the two seasons at the rates of $2.107 \mathrm{C}$ ton $\mathrm{fed}^{-1}+37.50 \mathrm{~kg} \mathrm{~N}^{-1}$ for wheat plants and 3.371 ton $C$ fed $^{-1}+60 \mathrm{~kg} \mathrm{~N}^{-1}$ fed $^{-1}$ for maize plants. This result may be due to this treatment gave the highest values of wheat and maize grain yields. Similar results were obtained by Tayebeh et al. (2010), Ahmad et al. (2013) and Adugna (2016). 
Table (8): Input production items and output of the experiments through the two growing seasons under study (winter 2018/2019 and summer 2019).

\begin{tabular}{|c|c|c|c|c|c|c|}
\hline Items & \multicolumn{4}{|c|}{ Treatment } & \multirow[t]{2}{*}{ Unit } & \multirow{2}{*}{$\begin{array}{l}\text { Unit } \\
\text { price } \\
\text { (LE) }\end{array}$} \\
\hline Input & First season & Second season & & & & \\
\hline Compost & 4.213 & 6.742 & ton/fed & \multirow{4}{*}{$\begin{array}{l}\text { and all possible } \\
\text { combination of } \\
\text { these parameter } \\
\text { in both seasons }\end{array}$} & Ton & 230.00 \\
\hline Nitrogen fertilizer & 75.00 & 120.00 & $\mathrm{Kg} \mathrm{fed}^{-1}$ & & $\mathrm{Kg} \mathrm{N}$ & 9.55 \\
\hline Phosphorus fertilizer & 15.50 & 31.00 & $\mathrm{Kg} \mathrm{fed}^{-1}$ & & $\mathrm{Kg} \mathrm{P}_{2} \mathrm{O}_{5}$ & 10.97 \\
\hline Potassium fertilizer & \multicolumn{3}{|c|}{ Recommended dose in both seasons } & & $\mathrm{Kg} \mathrm{K}_{2} \mathrm{O}$ & 25.00 \\
\hline Seeds of wheat & 60 & kg fed $^{-1}$ & & & $\mathrm{Kg}$ & 7.67 \\
\hline Seeds of maize & 15 & $\mathrm{~kg} \mathrm{fed}^{-1}$ & & & Kg & 23.00 \\
\hline Land preparation & & & & & per fed & 1000 \\
\hline labor & & & & & per fed & 1100 \\
\hline pesticides & & & & & per fed & 1000 \\
\hline Other costs & & & & & per fed & 600 \\
\hline \multicolumn{7}{|l|}{ Output } \\
\hline Wheat grain & & & & & Ton & 4467.00 \\
\hline Wheat straw & & & & & Ton & 1000.00 \\
\hline Maize grain & & & & & Ton & 2105.00 \\
\hline
\end{tabular}

Table (9): The net revenue * (LE/fed.) due to different treatments through the two growing seasons under study.

\begin{tabular}{|c|c|c|c|c|c|c|c|c|}
\hline \multirow{2}{*}{ 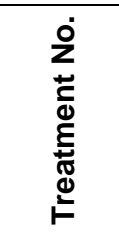 } & \multicolumn{3}{|c|}{ Increasing yield ton fed ${ }^{-1}$} & \multicolumn{3}{|c|}{ Total yield price, LE/fed. } & \multirow[b]{2}{*}{$\begin{array}{c}\text { Total } \\
\text { cost of } \\
\text { soil } \\
\text { addition }\end{array}$} & \multirow[b]{2}{*}{$\begin{array}{l}\text { Net } \\
\text { revenue } \\
\text { LE/fed. }\end{array}$} \\
\hline & $\begin{array}{l}\text { Wheat } \\
\text { grain }\end{array}$ & $\begin{array}{l}\text { Wheat } \\
\text { straw }\end{array}$ & $\begin{array}{l}\text { Maize } \\
\text { grain }\end{array}$ & $\begin{array}{l}\text { Wheat } \\
\text { grain }\end{array}$ & $\begin{array}{l}\text { Wheat } \\
\text { straw }\end{array}$ & $\begin{array}{l}\text { Maize } \\
\text { grain }\end{array}$ & & \\
\hline 1 & 1.4038 & 1.1665 & 0.4965 & 6270.77 & 1166.50 & 1045.13 & 2519.65 & 5962.75 \\
\hline 2 & 1.2312 & 1.1501 & 0.3548 & 5499.77 & 1150.10 & 746.85 & 1862.25 & 5534.47 \\
\hline 3 & 0.8502 & 0.8067 & 0.0238 & 3797.84 & 806.70 & 50.10 & 510.11 & 4144.53 \\
\hline 4 & 1.6227 & 1.3220 & 0.5973 & 7248.60 & 1322.00 & 1257.32 & 2191.07 & 7636.84 \\
\hline 5 & 1.1324 & 0.9309 & 0.2091 & 5058.43 & 930.90 & 440.16 & 1514.99 & 4914.49 \\
\hline 6 & 1.1379 & 0.9960 & 0.2408 & 5083.00 & 996.00 & 506.88 & 1186.18 & 5399.70 \\
\hline 7 & 1.1464 & 1.1160 & 0.2547 & 5120.97 & 1116.10 & 536.14 & 1629.04 & 5144.17 \\
\hline 8 & 1.2964 & 1.1194 & 0.4504 & 5791.02 & 1119.40 & 948.09 & 2071.90 & 5786.61 \\
\hline 9 & 1.3518 & 1.1231 & 0.4780 & 6038.49 & 1123.10 & 1006.19 & 1743.09 & 6424.69 \\
\hline 10 & 1.0013 & 0.8577 & 0.0628 & 4472.81 & 857.70 & 132.19 & 1067.01 & 4395.69 \\
\hline 11 & 1.5748 & 1.3047 & 0.5856 & 7034.63 & 1304.80 & 1232.69 & 2002.17 & 7569.94 \\
\hline 12 & 1.0215 & 0.9159 & 0.1578 & 4563.04 & 915.90 & 332.17 & 1551.90 & 4259.21 \\
\hline 13 & 1.0881 & 0.9048 & 0.1827 & 4860.54 & 904.90 & 384.58 & 1332.94 & 4817.08 \\
\hline Control & 0.0000 & 0.0000 & 0.0000 & 0000.00 & 000.00 & 000.00 & 0000.00 & 0000.00 \\
\hline
\end{tabular}

${ }^{*}=$ (Yield of treatment - control) - the cost of the treatment

The price of yield and the costs of different treatments were calculated as subsidized price of 2018 and 2019. 


\section{Conclusions}

It is more useful to use compost (C), Nitrogen (N) and phosphorus (P) fertilizers and their combinations to get a markedly improve in soil physical and chemical properties which reflect on highest yield in incorporated with high net revenue.

\section{REFERENCES}

Adugna, G. (2016). A review on impact of compost on soil properties, water use and crop productivity. Academic Res. J. Agric. Sci. and Res., 4(3): 93-104.

Ahmad, W., Z. Shah, F. Khan, S. Ali and W. Malik (2013). Maize yield and soil properties as influenced by integrated use of organic, inorganic and biofertilizers in a low fertility soil. Environ. j., 32(2): 121-129.

Almaz, M. G., R. A. Halim, M. Y. Martini and A. W. Samsuri (2017). Integrated application of Poultry manure and chemical fertiliser on soil chemical properties and nutrient uptake of maize and soybean. Malaysian J. Soil Sci., 21(1): 13-28.

Amit, K., B. P. Dhyani and K. Arvind (2018). Effect of timing of vermicompost application with different levels of NPK on periodic changes in soil properties. J. Experimental Zoology, India., 21(2): 1337-1341.

Bandyopadhyay, K.K., A.K. Misra, P.K. Ghosh and K.M. Hati (2010). Effect of integrated use of farmyard manure and chemical fertilizers on soil physical properties and productivity of soybean. Soil and Till. Res., 110: 115-125.

Bharath, T., G. E. C. H. Vidyasagar, V. P. Rao, S. N. Reddy and A. Madhavi (2017). Influence of organic manures integrated with inorganic fertilizer on soil properties after harvest of crops in maize-groundnut crop sequence. Environ. Ecology, 35(3): 1759-1764.

Black, C. A. (Ed.) (1965). Methods of soil analysis. Parts 1 and 2. Amer. Soc. Agron. No. 9, Madison, Wisconsin USA.

Brown, S. and M. Cotton (2011). Changes in soil properties and carbon content following compost application: results of on-farm sampling. Compost Science and Utilization, 19 (1): 88-97.

Chopra, R., M. Sharma, S. K. Sharma, V. Nepalia, H. K. Jain and A. Singh (2016). Effect of integrated nutrient management on growth and yield of wheat (Triticum aestivum L.) in Haplustepts. Ind. J. Sci. and Nat., 7(3): 622-628.

El-Maddah, E. I., M. El-D. El-Sodany and A. A. Mahmoud (2012). Effect of different tillage systems and soil conditioners on some soil chemical properties and status of nutrients. Egypt. J. of Appl. Sci., 27 (12): 968-995

El-Sodany, M. EI-D., E. I. El-Maddah and K.A. Khatab (2009). Effect of organic matter and inorganic phosphorus application on some physical, hydrophysical properties and soil productivity. Egypt. J. of Appl. Sci., 24(7): 396-421.

Gamal, A.R. (2009). Impacts of compost on soil properties and crop productivity in the Sahel North Burkina Faso. American- Eurasian J. Agric. and Envi. Sci., 6(2): 220 -226.

Gomaa, M.A., F. I. Radwan, I. F. Rehab and W. S. Mabrouk (2015). Response of bread wheat to organic and nitrogen fertilization. Middle East Journal of Agriculture Research, 4(1): $712-716$

Hesse, P. P. (1971). A Text Book of Soil Chemical Analysis -John- Murray (pupils.), London Great Britan. 
Israelsen, O. W. and V. E. Hansen (1962). Irrigation principles and practices. $3^{\text {rd }}$ Edit. John Wiley and Sons. Inc. New York.

Jensen, M. E. (1983). Design and Operation of Farm Irrigation System. Am. Soc. Agric. Eng. Michigan U.S.A.

Jinwei, Z. and Z. Lianren (2011). Combined application of organic and inorganic fertilizers on black soil fertility and maize yield. $J$. of Northeast Agric. Univ., 18(2): 24-29.

Keener, H.M., W.A. Dick and H.A. Hoitmk (2000). Composting and beneficial utilization of composted by-products materials. In USA. Land application of agricultural, industrial and municipal by-products, SSS a Book series No. 6: 315-341.

Liang, Q., H. Chen, Y. Gong, M. Fan, H. Yang and R. Lal (2012). Effects of 15 years of manure and inorganic fertilizers on soil organic carbon fractions a wheat-maize system in the North China Plain. Nutr. Cycling Agroecosyst., 92:21-33.

Liu, B., M. L. Gumpertz, S. Hu and J. B. Ristaino (2007). Longterm effects of organic and synthetic soil fertility amendments on soil microbial communities and the development of southern blight. Soil Biology and Biochemistry 39 (9): 2302-2316.

Mahmood, F., I. Khan, U. Ashraf, T. Shahzad, S. Hussain, M. Shahid and S. Ullah (2017). Effects of organic and inorganic manures on maize and their residual impact on soil physicochemical properties. J. Soil Sci. and Plant Nutrition.,17(1): 22-32.

Mohammed, M. Y. (2017). Impact of land use and management practice on soil physical and chemical quality indicators of Vertisols at Pawe,
Northwestern Ethiopia. African J. Agric. Res. 12(15): 1306-1313.

Moussa, K.F, N.N. Youssef and I.R. Mohamed (1986). A computer model on fertilizers application to plants. Egyptian. Soc. crop sci. proc. $2^{\text {nd }}$ conf. Agron. Alex. Egypt, 1: 649-662.

Moussa, K.F. (1991). Evaluation of the relative affinities of exchangeable cation in the alluvial soil of ElSharkiya Governorate. Zagazig J. Agric. Res., 18(4) 1151-1160.

Moyin-Jesu, E. I. (2015). Use of different organic fertilizers on soil fertility improvement, growth and head yield parameters of cabbage (Brassica oleraceae L). Intern. J. Recy. Organic Waste in Agriculture., 4(4): 291-298.

Richards, R. L. (1954). Diagnosis and Improvement of Saline and Alkali Soils. Agriculture Handbook No. 60, US Guvt. Printing office, Washington.

Smith, S.R. (1992). Sewage sludge and refuse composts as peat alternatives for conditioning impoverished: effects on the growth response and mineral status of petunia grand flora, J. Hort. Sci., 117 (5): 703-706.

Stakman, W. P. (1969). Determination of Soil Moisture Retention Curves. I. Sand-box apparatus. II. Pressure membrane apparatus. ICU, Wageningen, The Netherlands.

Tayebeh, A., A. Abass and A. K. Seyed (2010). Effect of organic and inorganic fertilizers on grain yield and protein banding pattern of wheat. Australian Journal of Crop Science., 4(6): 384389.

Vomocil, J. A. (1986). Particle-Size Analysis "In Methods of Soil Analysis". C.F. Klute, A.(Ed.) Part 1. Agron.9, 15, 299, Am. Soc. Agron. Madison, Wisconsin. U.S.A. 
التنبؤ بالتأثير المتذاخل من الكمبوست وأسمدة النتروجين والفوسفور على بعض خصائص التربة وإنتاجية محصولى القمت والذرة.

\author{
يسري أحمد محمود عبد الله
}

معهد بحوث الأراضي والمياه والبيئة، مركز البحوث الزراعية، الجيزة، مصر.

الملخص العربي

أجريت تجريتين حقليتين على أرض طينية خلال موسمين متعاقبين، الموسم الثتوي 2018/ 2019 باستخذام نباتات

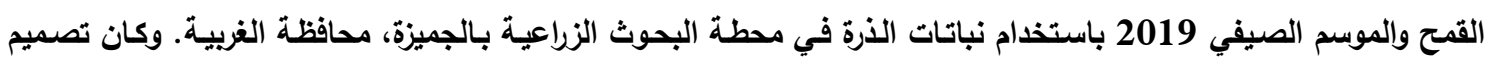

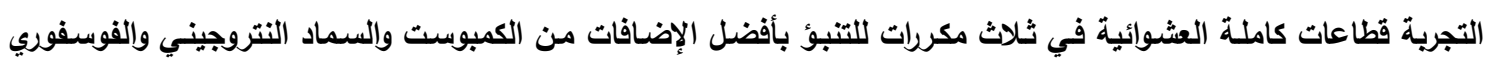

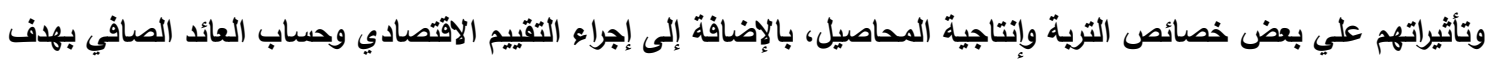

تحديد أفضل معاملة اقتصاديا.

والشتملت التجرية على ثلاثة عشر معاملة لتغطية كل التوافقات المحتملة من الكمبوست والنتروجين والفوسفور بالإضافة إلى التى

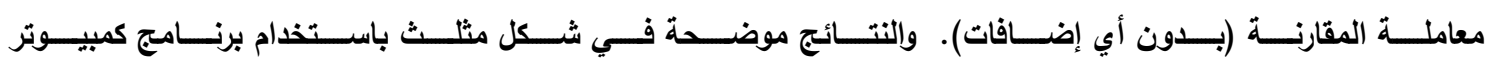

ثلاثي العوامل.

ويمكن تلخيص النتائج المتحصل عليها كالآتي:

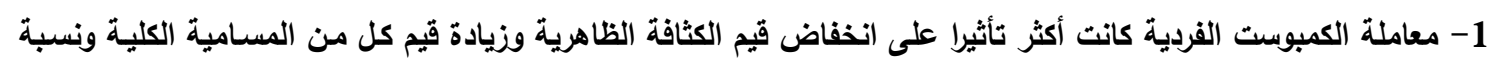

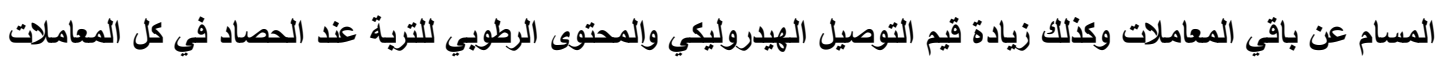

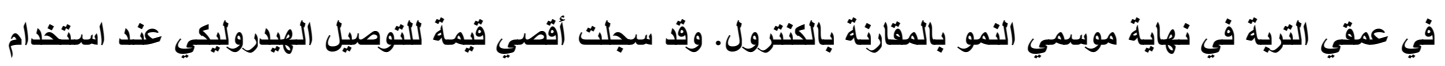
100\% كمبوست أو 90\% كمبوست + 10\% نتروجين. أيضا فإن التداخلات بين (الكمبوست، النتروجين) و (الكمبوست،

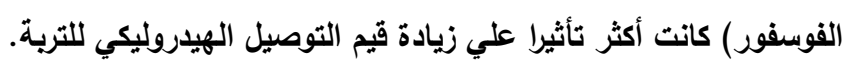

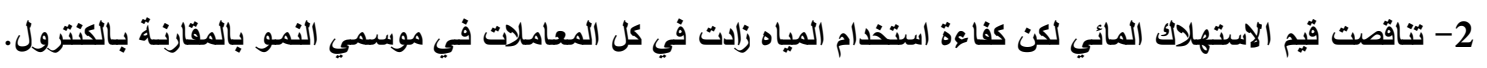

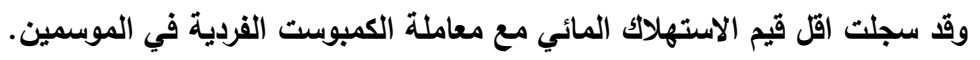

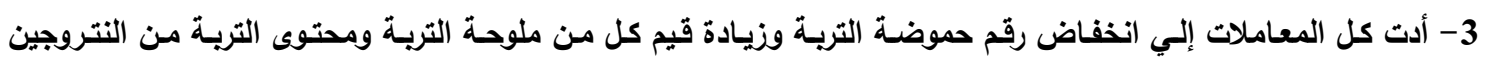

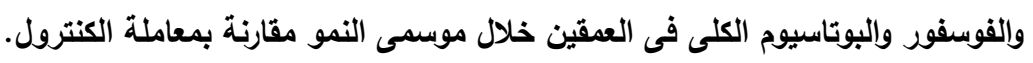
4- إضافة 100\% من الكمبوست أعطت اعلي قيم من الكريون العضوي، حيث أن الكمبوست كان أكثر تأثيرا في زيادة الكريون

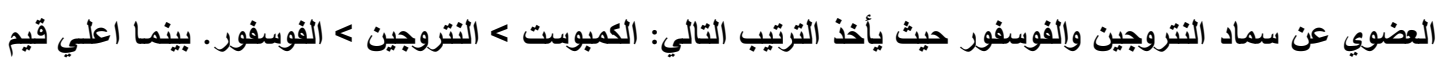

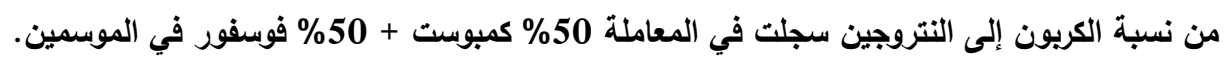

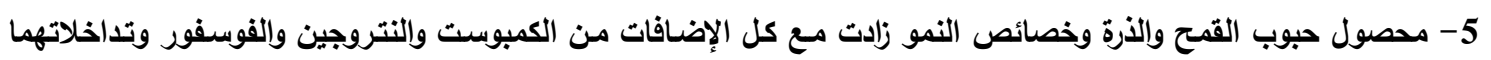

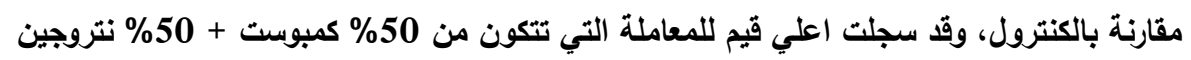

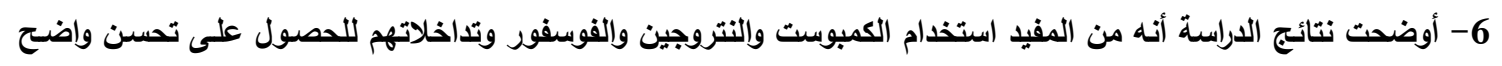

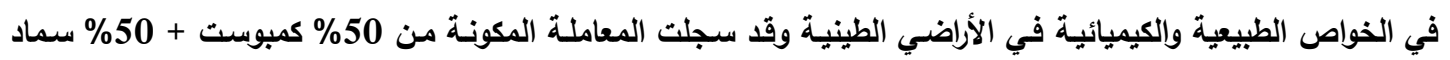
نتروجين أعلى محصول وأعلي صافي دخل مزرعي (7636,84 جنيه / فدان) في الموسمين. أسماء السادة المحكمين كلية الزراعة - جامعة الزقازيق كلية الزراعة - جامعة المنوفية

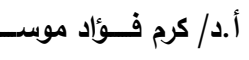
أ.د/ الحسينى عبدالغفار أبو حسين 